\title{
Diverse Ecological Pathways of Salmon Nutrients Through an Intact Marine-terrestrial Interface
}

\author{
THOMAS E. REIMCHEN \\ Department of Biology, University of Victoria, P.O. Box 3020, Victoria, British Columbia V8W 3N5 Canada; email: \\ reimchen@uvic.ca
}

Reimchen, Thomas E. 2017. Diverse ecological pathways of salmon nutrients through an intact marine-terrestrial interface. Canadian Field-Naturalist 131(4): 350-368. https://doi.org/10.22621/cfn.v131i4.1965

Based on five years of field studies (1992, 1993, 1994, 1998, 2000), I quantified bi-directional movement of salmon nutrients through an estuary, stream, and old growth forest in a large protected reserve on Haida Gwaii, British Columbia. In 1993, when most data were collected, about 6000 Chum Salmon (Oncorhynchus keta) entered the river of which $22 \%$ of the total biomass of senescent carcasses were swept downstream into the estuary and were scavenged by gulls $(n=350)$ and subtidal invertebrates. Of the 3700 salmon $(10000 \mathrm{~kg})$ transferred by American Black Bear (Ursus americanus) to the riparian zone and partially consumed along the $800 \mathrm{~m}$ of stream channel, $5070 \mathrm{~kg}$ of salmon tissues abandoned by the bears were scavenged by Northwestern Crows (Corvus caurinus; $n=200$ ) but mostly $(4100 \mathrm{~kg}$ ) by calliphorid blowfly larvae resulting in larval densities averaging $240 / \mathrm{m}^{2}$ throughout the riparian zone. Total nitrogen input to the soils from the combined effects of bear and scavenger activity as well as carcass input was $18 \mathrm{~g} / \mathrm{m}^{2}$ within $10 \mathrm{~m}$ of the stream channel. $\delta^{15} \mathrm{~N}$ of foliar tissues of Lanky Moss (Rhytidiadelphus loreus), Red Huckleberry (Vaccinium parvifolium), Salal (Gaultheria shallon), and Western Hemlock (Tsuga heterophylla) ranged about $15 \%$ to $20 \%$ among adjacent microsites in each species, with higher values occurring in salmon carcass zones. Total nitrogen in foliar tissues ranged from $1 \%$ to $2.4 \%$ among microsites and was best predicted by positive correlations with foliar ${ }^{15} \mathrm{~N}$ values and secondarily by presence/absence of salmon carcasses. This is the first study to integrate estuarine to riparian ecological processes in the cycling of salmonid nutrients and identifies a range of ecological baselines that can inform the multiple restoration programs underway in degraded watersheds in the North Pacific.

Key Words: Ancient forest; Calliphoridae; Corvus; ecological baselines; energy flow; Haida Gwaii; Larus; Oncorhynchus; spawning migration; Ursus

\section{Introduction}

A dominant cross-boundary subsidy at the marineterrestrial interface in the North Pacific is the yearly migration of adult salmon (Oncorhynchus spp.) to their natal spawning rivers. The importance of these migrations is widely recognized, not only for the marine predators and scavengers that aggregate in coastal and inshore waters (summaries in Willson and Halupka 1995; Cederholm et al. 1999, 2000; Hilderbrand et al. 2004), but also for terrestrial predators such as bears that disperse from higher elevation or inland areas to rivers and estuaries (Gilbert and Lanner 1995; Hilderbrand et al. 1996; Reimchen 2000; Gende et al. 2004). Historical records of salmon show declining biomass throughout the coast, particularly in southern watersheds (California, Oregon, Washington) where up to $95 \%$ of the salmon biomass has been lost over the last 100 years (Gresh et al. 2000). Presumably, this loss has negatively influenced the taxa that were trophically coupled to salmon biomass. While this is a reasonable inference for taxa such as bears (Gilbert and Lanner 1995), the influences on other consumers are unknown. This data deficiency emerges in part because the empirical partitioning of salmon biomass by multiple predator and scavenger taxa has not been described for any watershed and estuary in the North Pacific. Identifying such data in an intact marine-terrestrial food web would be useful not only for assessing basic trophic interactions among species but also for evaluating the potential impact of the historical decline in abundance of salmon.

The southern end of the Haida Gwaii archipelago, $100 \mathrm{~km}$ off the west coast of Canada, is a largely intact ecosystem with old growth forest and numerous small streams, most with spawning runs of Chum Salmon (Oncorhynchus keta) or Pink Salmon (O. gorbuscha). Salmon have declined in these watersheds and are approximately at $50 \%$ of the decadal averages observed during the 1940s and 1950s when yearly records were initiated (Marshall et al. 1978; Reimchen 2000). During autumn 1992, 1993, and 1994, I quantified predator and scavenger use of adult salmon in the estuary, stream, and riparian zones at Bag Harbour, one of the typical watersheds in the region. Several novel observations emerged during this early study, including the frequent nocturnal foraging by American Black Bear (Ursus americanus; Reimchen 1998) and their high transfer rate of salmon carcasses from the stream to the riparian zone (Reimchen 2000). This bear-mediated uploading of salmon had positive effects on annual growth of Sitka Spruce (Picea sitchensis (Bongard) Carriere), which was greater in microsites where carcasses were prevalent and greater during years when spawning runs were elevated (Reimchen and Fox 2013). In the current manuscript, I estimate the total mass of salmon used by 
each of the major mammalian, avian, and invertebrate foragers for the estuary, stream, and riparian habitats, estimate the total input of nitrogen into riparian soils, quantify the extent of enrichment of the marine-derived nitrogen $\left({ }^{15} \mathrm{~N}\right)$ in riparian plants, and examine foliar $\% \mathrm{~N}$ as a proxy for primary productivity across a spatial gradient of carcasses and bear activity.

\section{Methods}

Bag Harbour $\left(52.347^{\circ} \mathrm{N}, 131.366^{\circ} \mathrm{W}\right)$ occurs in a mountainous area on Moresby Island near the south end of Haida Gwaii (Figure 1). The small shallow harbour (33 ha, maximum depth $\sim 16 \mathrm{~m}$ ) has a broad intertidal zone with extensive cover of macrophytes (Fucus spp.) and lower intertidal and subtidal beds of eel grass (Zosteraceae). The harbour is bordered by ancient forest dominated by Sitka Spruce, Western Hemlock (Tsuga heterophylla (Rafinesque) Sargent), and Red Cedar (Thuja plicata Donn ex D. Don) with trees reaching 1000 years of age (Reimchen and Fox 2013) and classified as a very wet hypermaritime subzone 3 (CWHvh3 Site Series 110; Banner et al. 2014). There is a single major salmon-bearing stream $(5-10 \mathrm{~m}$ width, $<0.5 \mathrm{~m}$ depth, $<1^{\circ}$ gradient) which extends $1500 \mathrm{~m}$ between the estuary and a small headwater lake. Most of the spawning gravels are found from 300 to $800 \mathrm{~m}$ upstream from the estuary. Between 2300 and 6300 salmon enter the stream yearly, the majority $(>90 \%)$ of which are Chum Salmon with additional Pink Salmon, and Coho Salmon (O. keta), the latter using tributary streams to the headwater lake. Field surveys were initially made in 1992 during the second half of the salmon spawning period (8-21 October) and in 1993 throughout the spawning period (28 September26 October) with a supplemental survey two weeks after completion of the spawning run (13-14 November). In 1994, I made carcass counts midway through the spawning run (12-13 October) and near the end of the run (2-4 November). The site was also visited in 1998 (10-11 October) and again in 2000 (19-20 September). Additional details are given in Reimchen (1998, 2000) and Reimchen and Fox (2013). In 1992 and 1993, the major mammalian and avian foragers and scavengers were counted daily in early morning, midday, and late afternoon. Intermittently throughout the day, I recorded general predator and scavenging forag-

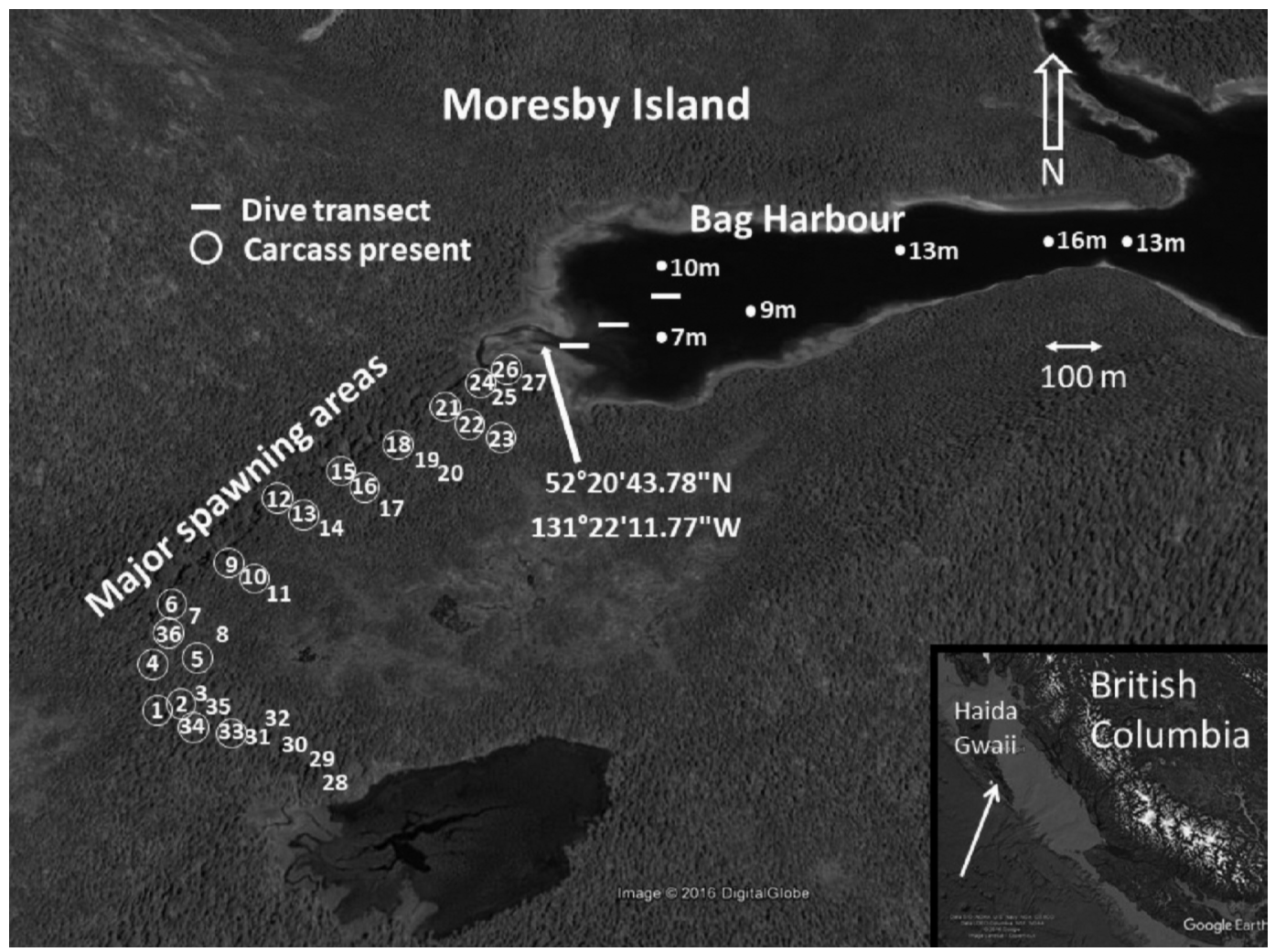

FiguRE 1. Bag Harbour, British Columbia study area. Microsites (\#1-35) for plant samples (2000). Circled microsites had Chum Salmon (Oncorhynchus keta) carcasses. Horizontal bars in estuary are sites of three SCUBA transects (1993). Water depth (closed circle) shown in meters (m). Source: Bag Harbour, Moresby Island, 52²0’43.78"N, 131²2’11.77"W. Google Earth. Imagery date: 6 September 2016. Accessed:1 March 2017. 
ing activity of each focal species and, where possible, type of tissues consumed (fresh salmon, senescent carcasses, eggs). Fungal and bacterial decomposers as well as stream macroinvertebrates were present on some carcasses, but the extent of their carcass use was not quantified. Songbirds, rodents, and shrews, although present in the watershed, were not commonly seen during the autumn surveys and were not quantified. In 1993, observations were extended throughout the night using helmet-mounted night-viewing goggles (Reimchen 1998). In October 1993, 40 undamaged salmon carcasses collected from the stream were measured for individual mass $( \pm 10 \mathrm{~g})$ and tethered every $3.4 \mathrm{~m}$ along each of three subtidal rope transects at $10 \mathrm{~m}, 75 \mathrm{~m}$, and $150 \mathrm{~m}$ distance from the stream mouth at depths increasing from $3 \mathrm{~m}$ to $10 \mathrm{~m}$ (Figure 1). Every 24 hours over the following seven days, I used SCUBA to survey each of the carcasses and recorded numbers of the dominant marine scavengers on the carcasses. During each survey, after removing scavengers, the carcass was brought to the surface and wet mass $( \pm 100 \mathrm{~g})$ determined, returned to the bottom, and re-tethered to the rope transect. By the fifth day, carcasses had begun to disintegrate and further weights were not possible.

The complete riparian zone between the estuary and the headwater lake was surveyed for carcasses during the spawning period twice in 1992, five times in 1993, and twice in 1994 yielding a cumulative yearly total transfer at the completion of the run of 1150,3611, and 1596 carcasses, respectively; for a $3 \mathrm{~kg}$ Chum Salmon, bears consumed an average of $1.6 \mathrm{~kg} /$ carcass and abandoned $1.4 \mathrm{~kg}$ (full details in Reimchen 2000). The majority of salmon carcasses were distributed within a $50 \mathrm{~m}$ riparian band adjacent to the dominant spawning reaches in the stream and with highest densities occurring within $10 \mathrm{~m}$ of the stream.

Carcass consumption by scavengers other than bears was determined with two methods. First, I tagged and weighed 152 fresh in situ complete salmon carcasses (1992, $n=89 ; 1993, n=63)$ abandoned by bears in the riparian zone and on successive days monitored any foraging activity on the carcasses. Following a foraging bout by a flock of birds, I re-examined the carcass and noted the type of tissues extracted. All carcasses were re-weighed every two days. Loss of mass from tissue dehydration was minimal due to the shade, moist substrate, and high humidity. Secondly, I used daily metabolic requirements combined with total days of presence for the common avian scavengers (e.g., Birtfriesen et al. 1989; Christie and Reimchen 2006). Blow flies (predominantly Calliphoridae) deposited eggs on carcasses within the first two days following transfer to the riparian zone and typically after three to five days, larvae dominated the carcasses. I estimated numbers of larvae per carcass using three separate methods: assume a density of 8 larvae per gram of tissue based on experimental forensic studies of Calliphorid larvae consuming liver (Goodbrod and Goff 1990), empirically-derived regression (number of larvae $=$ $268+3.0$ times carcass mass) based on dipteran larval production on Chum Salmon carcasses from mainland British Columbia (Hocking and Reimchen 2002), and empirical estimates of 22.4 larvae per g Sockeye Salmon (Oncorhynchus nerka) carcasses in Washington (Meehan et al. 2005). To determine density on the forest floor, I counted all larvae at seven plots $(20 \mathrm{~cm} \times$ $20 \mathrm{~cm}$ ) positioned at $0 \mathrm{~m}, 1 \mathrm{~m}, 2 \mathrm{~m}$, and $3 \mathrm{~m}$ from the bony remnants one day after no further larvae were visible on the remnants.

To assess soil invertebrates, I took paired $175 \mathrm{cc}$ soil plugs, the first from beneath the bony remnants, and a second $0.5 \mathrm{~m}$ distant from the first but on a similar substrate. The sites for the plugs were about $5 \mathrm{~m}$ from the stream bank and from 17 different sites extending over $100 \mathrm{~m}$ along the stream channel in the reaches of high spawning densities. Soil plugs were dried in separate Berlese funnels and all extracted invertebrates counted and identified to Order or Family.

In October 2000, a vegetation sampling grid was established in this watershed at 35 riparian sites between the estuary and the headwater lake, including 11 transects perpendicular from the stream into the forest across a previously documented gradient of high to low salmon carcass densities (Reimchen 2000). Within a $5 \mathrm{~m}$ radius of each targetted Sitka Spruce, the primary focus for the grid (Reimchen and Fox 2013), I sampled up to six plant species, the number dependent on their occurrence at each site: Lanky Moss (Rhytidiadelphus loreus (Hedw.) Warnst.), Deer Fern (Blechnum spicant (L.) Roth), Red Huckleberry (Vaccinium parvifolium Smith), False Azalea (Menziesia ferruginea J. E. Smith), Salal (Gaultheria shallon Pursh), and Western Hemlock seedlings, the latter from intact nurse logs which were typically large fallen Sitka Spruce. For each of the sites, I measured distance $(\mathrm{m})$ from the stream edge into the forest (DistForest). There was a gentle slope $\left(\sim 5^{\circ}\right)$ across the riparian zone. For each species and from each of three separate plants, I collected up to six leaves or needles that were later oven-dried at $60^{\circ} \mathrm{C}$ for $2-3$ weeks. One mg of tissue was powdered, packaged, and processed for nitrogen isotope signatures and total nitrogen at the Stable Isotope Facility, University of Saskatchewan, using a Europa Scientific ANCA NT gas/ solid/liquid preparation module coupled to a Europa Scientific Tracer 20-20 mass spectrometer (PDZ Europa, Cheshire, England). Four species were common throughout the sampling grid and I restrict analyses to these $(n=314)$. Natural abundance of ${ }^{15} \mathrm{~N}$ is expressed as the deviation from atmospheric $\mathrm{N}_{2}(\%)$ and calculated as $\delta^{15} \mathrm{~N}=\left(\mathrm{R}_{\text {sample }} / \mathrm{R}_{\text {standard }}-1\right)$ where $\mathrm{R}$ is the ratio of ${ }^{15} \mathrm{~N} /{ }^{14} \mathrm{~N}$ stable isotopes. Measurement precision is $\pm 0.35 \%$.

Relative contribution of marine-derived nitrogen (\%MDN) for each of the four plant species was calculated using:

$$
\% \mathrm{MDN}_{1}=\left(\mathrm{OBS}_{1}-\mathrm{TEM}_{1}\right) /\left(\mathrm{MEM}-\mathrm{TEM}_{1}\right)
$$


where $\mathrm{OBS}_{1}$ is the $\delta^{15} \mathrm{~N}$ value for species $1, \mathrm{TEM}_{1}$ is the terrestrial end member for species 1, and MEM is the value $\left(\delta^{15} \mathrm{~N}=11.1 \%\right.$ o for Chum Salmon, the marine end member (Johnson and Schindler 2009). For each species, I used a TEM for non-carcass sites that are sites greater than $60 \mathrm{~m}$ from the stream where no carcasses were observed, as well as sites greater than $1200 \mathrm{~m}$ upstream beyond the upper distribution of spawning gravels and where no carcasses were observed (\#20, 17, 14, 8, 11, 32, 30, 29, 28; Figure 1).

\section{Statistics}

All analyses were run using SPSS v.24 (IBM, USA). For the 17 pairs of adjacent soil plugs, numbers of individuals (ln transformed) for each taxon were compared with paired $t$-tests while diversity was estimated using Shannon Diversity (H) and Equitability (E) indices. Foliar $\delta^{15} \mathrm{~N}$ values for each of the four riparian species were normally distributed while $\% \mathrm{~N}$ values violated assumptions of normality due to the strong positive skew of the data (Shapiro-Wilk, $P>0.05$ ). Log transformations did not normalize the data so I used Box-Cox rank transformations. To visualize the spatial trends in the data, I initially plotted $\delta^{15} \mathrm{~N}$ for each species on a grid of the riparian microsites for distance upstream from the estuary and for distance into the forest in relation to presence or absence of salmon carcasses at the microsite. Secondly, I saved the $\delta^{15} \mathrm{~N}$ residuals for each species and plotted the combined data on the grid. In each species, $\delta^{15} \mathrm{~N}$ and $\% \mathrm{~N}$ were positively correlated with each other. To identify whether the presence/absence of a carcass was associated with these nitrogen variables, I ran a multivariate general linear model (GLM) using $\delta^{15} \mathrm{~N}$ and $\% \mathrm{~N}$ as dependents, Carcass (absence/presence) as a categorical independent variable, and DistForest as covariate. I then tested the main effect of Carcass on $\delta^{15} \mathrm{~N}$ and $\% \mathrm{~N}$ for each species.

\section{Results}

Basic food web

A simplified energy flow diagram of salmon at Bag Harbour is shown in Figure 2. Of the 6300 pre-spawned salmon returning from the open ocean in 1993, predation in the estuary, primarily by bears and pinnipeds, resulted in a $4 \%$ reduction of the total salmon biomass. The majority of salmon (96\%) migrated upstream for spawning and approximately $20 \%$ of the post-reproductive carcasses were swept downstream into the estuary. These carcasses were scavenged by avian taxa and subtidal invertebrates. In the stream channel, bears captured or scavenged about $65 \%$ of the salmon, most of which $(n=3700)$ were transferred to the riparian zone, where bears consumed about one-half of each carcass. Gulls and crows scavenged about $7 \%$ of total carcass biomass on stream gravel bars and $12 \%$ of the carcass biomass in the riparian zone. Most of the soft tissues of riparian carcasses abandoned by bears were consumed by calliphorid larvae. In 1992, there were approximately half the carcasses compared with 1993. Taxonomic diversity and total numbers of individual taxa seen in the estuary and watershed are summarized in Table 1. Most species were uncommon in the watershed prior to the salmon migration.

\section{Mammals}

Pinnipeds occurred in the estuary throughout the salmon spawning period, usually in low numbers during both years. Foraging on salmon was observed both during daylight and darkness, the latter facilitated by extensive bioluminescence produced during movement of the salmon. In autumn 1992, I recorded 42 daylight pursuits by Harbour Seals (Phoca vitulina) of which five were successful (12\%). I could not determine success of the nocturnal pursuits. Handling and ingestion occurred at the surface and typically involved secondary scavenging by gulls (primarily Herring [Larus argentatus] and Glaucous-winged [L. glaucescens]) on the floating tissue remnants. Based on these observations, the total number of 'seal days' as well as the average daily salmon consumption of Harbour Seals $(1.9 \mathrm{~kg} /$ day $)$ in an estuary in southern British Columba (P. Olesiuk, personal communication, December 1994), I estimated total capture/spawning run of approximately 80 salmon (1992: $266 \mathrm{~kg}$; 1993: $239 \mathrm{~kg}$ ). Up to four Steller Sea Lion (Eumetopias jubatus) also occurred in the estuary over the spawning period during both years, primarily during twilight and darkness. I could not reliably determine their foraging activities but combining the total 'sea lion days' at Bag Harbour and the daily salmon consumption of sea lions on Vancouver Island (G. Ellis, personal communication, December 1994), I estimated salmon consumption by sea lions in 1992 and 1993 at 80 and 10 salmon respectively (1992: $240 \mathrm{~kg}$; 1993: $30 \mathrm{~kg}$ ).

From four to eight Black Bears occurred in the watershed throughout the salmon spawning period. Summarizing from Reimchen (1994, 2000), a total of 4790 salmon were captured in 1993 of which 1030 were consumed in the stream channel while 3700 (10 $970 \mathrm{~kg}$ ) were transferred into the riparian zone for consumption (the others were in the estuary). These carcasses were most prevalent in riparian zones adjacent to high stream spawning densities. Most (80\%) carcasses were dropped within $10 \mathrm{~m}$ of the stream with numbers declining at greater distances into the forest. Occasional carcass remnants could be found on bear trails up to $80 \mathrm{~m}$ from the stream. Mass of individual carcass remnants abandoned by bears averaged $1.3 \mathrm{~kg}(n=689)$ and ranged from $2 \%$ to $98 \%$ (average $=44 \%$ ) of original carcass mass estimated from jaw length (Reimchen 2000). Percentage of each carcass abandoned by the bears was higher $(\sim 75 \%)$ following new migration of spawners into the stream (during rainfall and increased stream flow) and was lower ( $35 \%)$ when salmon densities in the stream were low (following multiple days without rainfall). Based on the overall distribution and abundance of bear-transferred carcasses throughout the watershed, general density of abandoned tissues 
Crows, Gulls, Marten

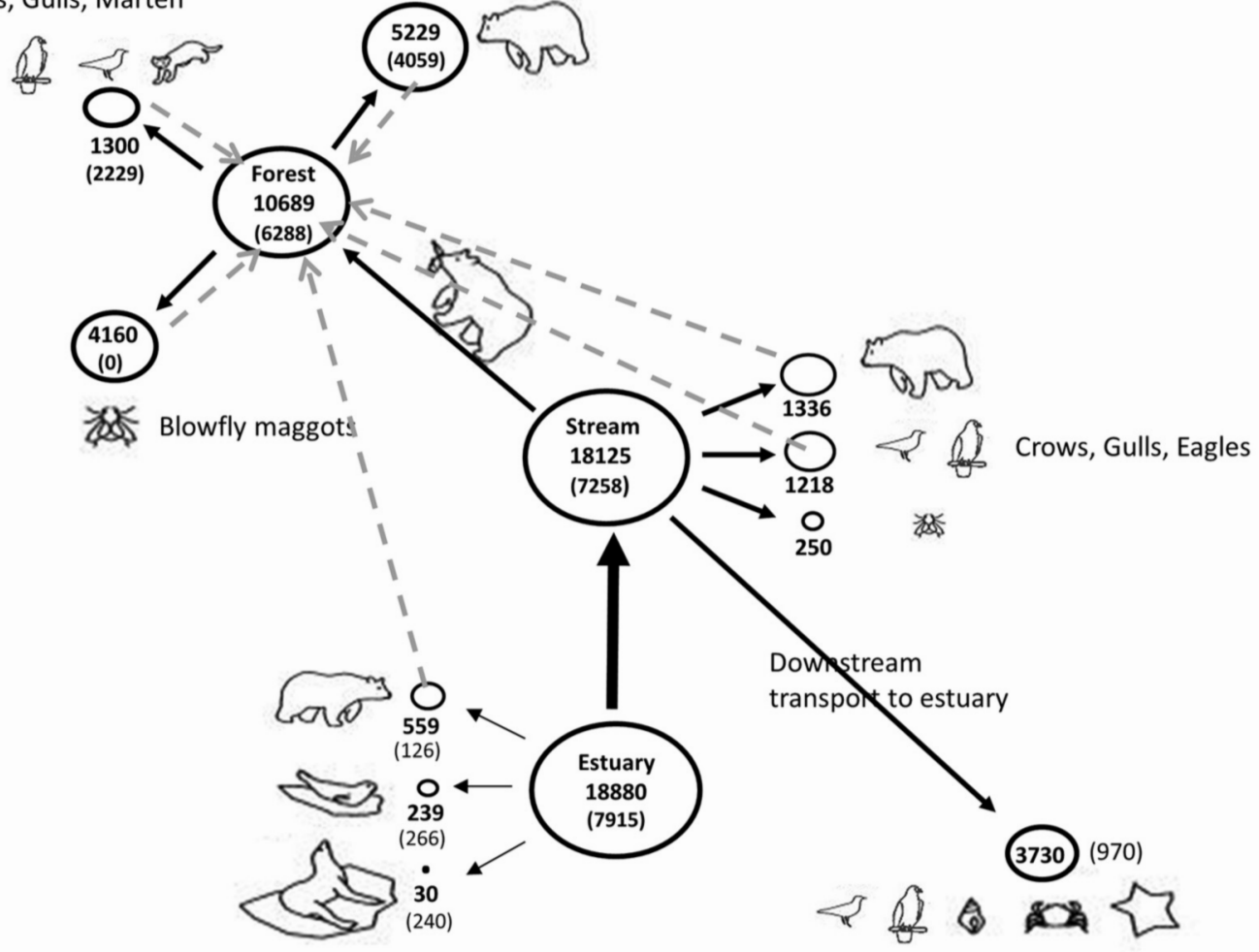

Intertidal and subtidal scavengers

FIGURE 2. Summarized Chum Salmon (Oncorhynchus keta) nutrient flow at Bag Harbour, British Columbia for 1993 and 1992 (in brackets). All values shown in $\mathrm{kg}$. Area of circle proportional to original biomass entering estuary. Dashed lines show dominant sources of nitrogen input to soil. See Table 1 for a complete list of all major taxa examined.

was $2730 \mathrm{~kg} / \mathrm{ha}$ within a $10 \mathrm{~m}$ band adjacent to the stream and $171 \mathrm{~kg} /$ ha further into the forest $(10-50 \mathrm{~m})$.

Small mammals were also resident in the watershed. Two American Marten (Martes americana) were commonly observed on the stream banks feeding on fresh carcass tissues abandoned by bears. I did not see any use of the much more abundant senescent carcasses by this scavenger. Based on direct observation, I estimated total salmon consumption by marten of $\sim 20 \mathrm{~kg}$ in 1993. During a mid-November visit to the stream two weeks after the spawning run, I found 14 freshly killed gulls cached under trees adjacent to the stream channel where marten had been previously observed dragging fresh salmon remnants and I infer that these caches were made by the marten. On multiple occasions, gulls were seen resting on stream banks following extended bouts of salmon carcass consumption and I suspect this made them highly susceptible to capture by marten. As I only searched about a quarter of the root cavities in the spawning reaches, the 14 carcasses are probably a substantial underestimate of the total in the watershed. Several resident River Otter (Lontra canadensis) foraged for Coho Salmon in the tributary streams to the headwater.

\section{Birds}

Twenty-seven species of birds were recorded in the watershed during the study period (Table 1). Most were uncommon prior to and early in the spawning migration but increased over the duration of the spawning run. Scavenging occurred in nine species including multispecies flocks of gulls (primarily Herring and Glaucous-winged) reaching a maximum $(n=375)$ in midOctober and then declining towards the end of the spawning run. Near dawn and dusk, gulls consumed salmon eggs drifting from the stream into the estuary but also scavenged carcasses in the intertidal zone. During daylight, most gulls moved upstream from the estuary where they foraged on dislodged salmon eggs, senescent carcasses in the stream channel, and bearabandoned carcasses on the gravel bars and stream banks. Based on the daily loss of carcass mass in addition to number of 'gull days', I estimate a total consumption of $900 \mathrm{~kg}$ of salmon tissues. Using daily metabolic requirements and cumulative 'gull days' yields an independent but similar estimate of $1160 \mathrm{~kg}$ of tissue. Northwestern Crows ( 200) were prevalent on the estuary during the first two weeks of the spawning run but shifted upstream to riparian habitats in the 
TABLE 1. Major taxa examined at Bag Harbour watershed, Haida Gwaii, British Columbia, during Chum Salmon (Oncorhynchus keta) migration. Counts of individual animals show daily maxima and averages for 1993 (most detailed) and 1992 (brackets). Chum Salmon spawning numbers are 6300 (1993) and 2700 (1992). Riparian vegetation samples were collected in October 2000 (for $\delta^{15} \mathrm{~N}$ and $\% \mathrm{~N}$ ) and show sample sizes for each species. $\mathrm{nc}=$ not counted.

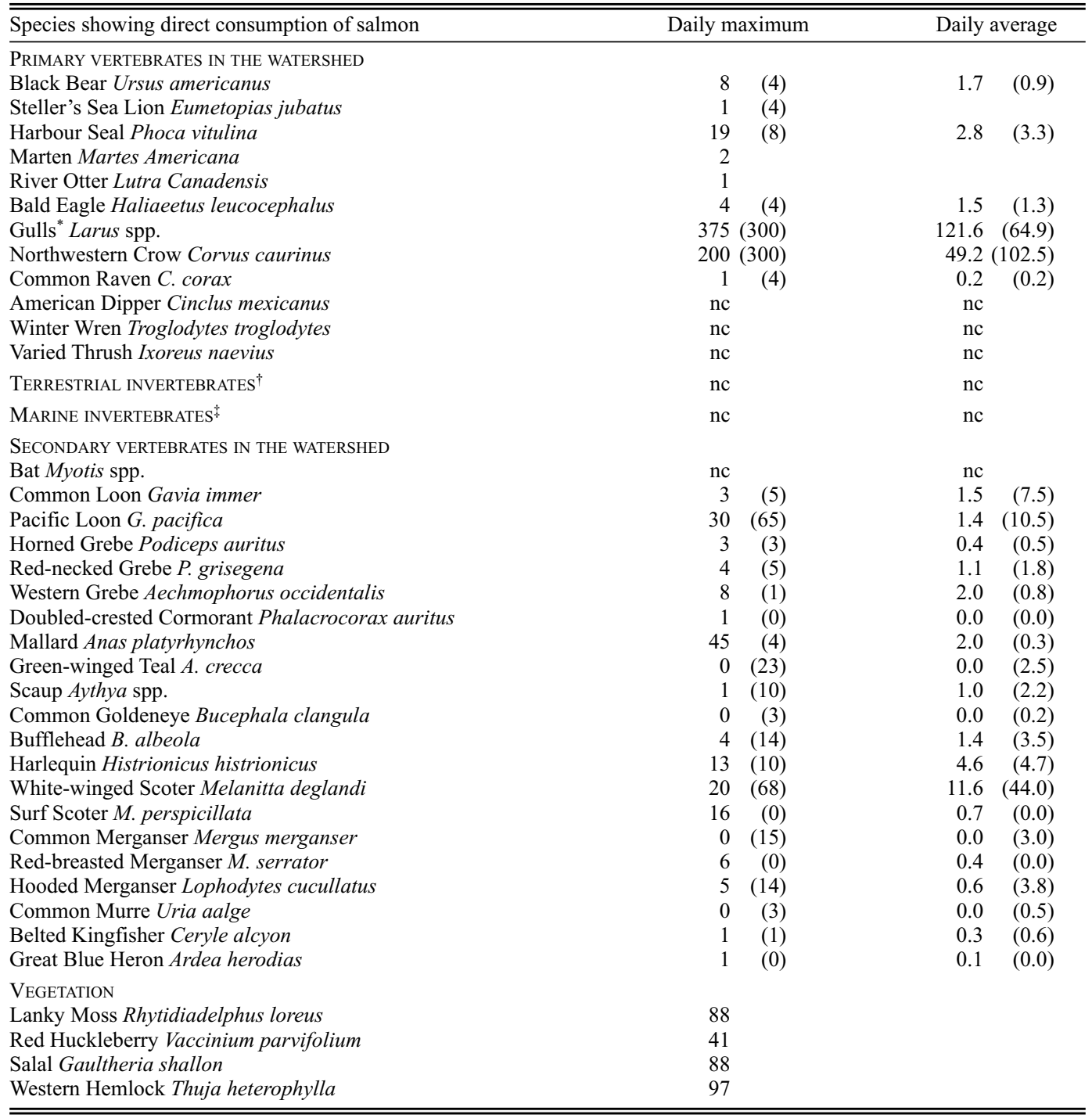

*Primarily Glaucous-winged Gull (Larus glaucescens) and Herring Gull (L. argentatus).

†Terrestrial invertebrate data obtained in October 1993 (24 taxa; Figure 3).

* Gastropoda, Crustacea, Echinodermata.

second half of the run (30 September to 20 October). They usually occurred in small flocks (10-30 individuals) in the immediate vicinity of bears that were feeding on freshly-captured salmon in the stream or the riparian zone and would quickly occupy the remnants when the bears abandoned the carcass. I did not observe crows foraging on senescent carcasses or on fly larvae that were prevalent in the riparian zone. Combining daily estimates of crow abundance ( 2800 'crow days') and their general foraging activity throughout the spawning run yields an estimated total consumption of $270 \mathrm{~kg}$. Two weeks after the end of the spawning run, no crows were observed in the estuary, stream, or riparian zone.

Among the birds foraging in the estuary, 21 species occurred that were either minor salmon consumers or were not directly associated with carcasses. Bald Eagle (Haliaeetus leucocephalus; maximum four) occurred daily throughout the spawning period and based on 
direct observation of their foraging activity, I estimate a total consumption of $\sim 20 \mathrm{~kg}$ of fresh salmon tissues abandoned by bears. However, based on daily salmon consumption rates of captive Bald Eagles at $5{ }^{\circ} \mathrm{C}$ (Stalmaster and Gessaman 1982), the four Bald Eagles at Bag Harbour would consume $60 \mathrm{~kg}$ over the spawning period. Common Ravens were intermittently present (maximum four) and foraged on fresh salmon carcass remnants abandoned by bears and I estimate total consumption at $5 \mathrm{~kg}$. American Dipper (Cinclus mexicanus; maximum three) foraged on salmon eggs in the stream throughout the study period (no biomass estimated). Eighteen bird species, not seen in direct association with salmon carcasses, appeared in the estuary following the onset of the spawning run and were present throughout the duration of the run. Foraging by each species was common every day. During SCUBA transects, I observed large schools of clupeid-like fish in areas where diving birds (primarily Pacific Loon [Gavia pacifica]) were present and I infer these were the target of the divers. White-winged Scoters (Melanitta fusca) were prevalent near the stream mouth and consumed drifting salmon eggs, carcass remnants, and small crustaceans associated with the submerged salmon carcasses. Mallards (Anas platyrhynchos) became very common on the estuary after the completion of spawning run but I was not able to identify prey items of these dabblers.

\section{Terrestrial invertebrates}

Invertebrate scavengers, primarily calliphorid blowfly larvae, were major consumers of salmon carcasses but their abundance was highly variable among years. In autumn 1992, when 2000 salmon were transferred by bears to the riparian zone, I did not observe any carcasses with blowfly eggs or larvae. In contrast, in autumn 1993, when 3700 carcasses were transported by bears to similar regions of the riparian areas as in $1992,95 \%$ of carcasses had blowfly egg masses and these hatched within several days resulting in high densities of larvae that fully enveloped the carcass remnants. Daily surveys to these carcasses showed consumption of all soft tissues by the larvae in five to seven days. Total counts of larvae per carcass, assuming a $1.3 \mathrm{~kg}$ average carcass mass of abandoned tissues, are estimated at 4200 based on estimates derived from Hocking and Reimchen (2002), 10400 based on the eight larvae/gram of tissue from Goodbrod and Goff (1990), and 29000 based on empirical counts on Sockeye Salmon by Meehan et al. (2005). I will assume the conservative estimate. Larvae dispersed radially from the bony remnants and direct counts of dispersing larvae ranged from $\sim 7000 / \mathrm{m}^{2}$ within a half meter radius of the remnants to $200 / \mathrm{m}^{2}$ at $3 \mathrm{~m}$ distance from any carcass remnants. Pre-pupal larvae burrowed into the moss-substrate, under and within woody debris, and were observed under the bark several metres up the vertical trunks of trees. Based on $95 \%$ of the carcasses with larvae, I estimate there would be 14.7 million larvae produced during the 1993 spawning run. As $80 \%$ of the carcasses were within $10 \mathrm{~m}$ of the stream bank, average densities of dispersing larvae on the substrate would be $738 / \mathrm{m}^{2}$ while further into the riparian zone $(10-50 \mathrm{~m})$ this would be reduced to 31 larvae $/ \mathrm{m}^{2}$ along the $800 \mathrm{~m}$ riparian band on each side of the spawning gravels. I found minimal evidence for mortality of the larvae either at the carcass site or during their subsequent dispersal on the forest floor. Despite monitoring hundreds of carcasses, the pungent odour and high temperatures of the dense larval masses appeared to exclude most other scavengers. Among the multiple bear scats observed, a single scat had large volumes of digested larvae indicating occasional consumption of these larvae-dominated carcasses or of dispersing larvae. Some larvae dispersed over the stream bank and were swept downstream.

Paired soil plugs ('below' bony remnants versus 'adjacent' to bony remnants) extracted from each of 17 separate carcass sites yielded 24 invertebrate taxa of which mites (Acari), springtails (Collembola), and dipteran larvae were the most abundant. Overall Shannon diversity $(\mathrm{H})$ and Equitability indices were similar for 'below' and 'adjacent' microsites $(\mathrm{H}=1.15$ and $1.7, \mathrm{E}=0.36$ and 0.36 , respectively). While twenty of these taxa showed no statistical difference between the two microsites (paired $t$-test, $P>0.1$ in all cases), four groups (mites, springtails, pseudoscorpions, and spiders) were more prevalent in the 'adjacent' microsite $(P<0.05$ in each taxa) and two taxa (dipteran larvae and staphylinid beetles) were more common 'beneath' the bony remnants $(P<0.05$ and $P<0.001$, respectively; Figure 3).

\section{Marine invertebrates}

SCUBA surveys of 40 tethered subtidal carcasses yielded 10 species of macro-invertebrate scavengers. In the shallow transect $(5 \mathrm{~m})$, the dominant scavenger on the carcasses was Dire Welk (Lirabuccinum dirum; average $=7$, range $0-250$ ) and less frequently hermit crabs (Pagurus spp. average $=2.5$, range $0-10$ ), beach crab (Hemigrapsus spp. average $=0.4$, range $0-10$ ), Red-rock Crab (Cancer productus average $=0.9$, range 0-4), broken-back shrimp (Heptacarpus spp. average $=0.1$, range $0-5)$, and starfish (Evasterias spp. average $=0.1$, range $0-1)$. The middle depth transect $(10 \mathrm{~m})$ had Dire Welk (average $=20$, range 0-125), hermit crabs (average $=1.2$, range $0-4$ ), and broken-back shrimp (average $=2.7$, range $0-15$ ) while the deep transect $(15 \mathrm{~m})$ had Red-rock Crab (average $=1.4$, range $0-6$ ), starfish (Pisaster spp. average $=0.1$, range $0-2$ ), bat star (Asterina sp. average $=1.1$, range $0-9)$, Sunstar (Pycnopodia helianthoides average $=0.1$, range $0-1$ ) and Leather Star (Dermasterias imbricata average $=0.1$, range $0-1$ ). Based on the daily mass measurements of each carcass, there was an average loss of $200 \mathrm{~g} /$ day/carcass. Tissues became progressively softer and after five to seven days of submersion, attempted handling of these carcasses produced a cloudy fine suspension of tissues into the water column. This disso- 
lution was more rapid in carcasses from the shallow transects where Lirabuccinum snails dominated the carcasses. Secondary interactions with Lirabuccinum could be occurring after the spawning run as there was high abundance of recent crab-predated Lirabuccinum that had previously dominated the carcasses.

\section{Riparian nitrogen input}

Overall contribution of salmon-derived nitrogen to the riparian zone was estimated for the 1993 field season. Nitrogen comprises about $3.3 \%$ of total Chum Salmon mass (Gende et al. 2007) and when salmon are consumed by bears, most nitrogen is excreted as urine (96\%) or faeces (3\%; Hilderbrand et al. 1999). Therefore, of the $10690 \mathrm{~kg}$ uploaded by bears in 1993 along the $800 \mathrm{~m}$ of stream, $5230 \mathrm{~kg}$ was consumed, and $171.6 \mathrm{~kg}$ of nitrogen would be deposited on the forest floor. Of the $5460 \mathrm{~kg}$ of tissues abandoned by the bears in the riparian zone, most of this nitrogen $(180 \mathrm{~kg})$ would remain in the riparian zone from calliphorid larvae which pupated in the soil, scavenging by flocks of crows and gulls whose guano was scattered throughout the riparian zone, and by decomposition and direct leaching of the carcasses into the substrate. In total, $352 \mathrm{~kg}$ of salmon-derived nitrogen would be added to the riparian zone during the eightweek salmon spawning period. Eighty percent of the carcasses were within a $10 \mathrm{~m}$ band adjacent to the stream channel throughout the $800 \mathrm{~m}$ of the spawning activity. This zone contained most of the bear activity, calliphorid larval density, and avian scavenger activity. Nitrogen concentration would average $17.6 \mathrm{~g} \mathrm{~N} / \mathrm{m}^{2}$ in this band and $1.1 \mathrm{~g} \mathrm{~N} / \mathrm{m}^{2}$ in the $10 \mathrm{~m}-50 \mathrm{~m}$ zone band further into the forest. These could be conservative estimates as they do not include any contribution of the $1600 \mathrm{~kg}$ of salmon consumed directly in the stream channel by bears and avian scavengers. Both bears and crows typically moved into the riparian zone between foraging bouts and would have further supplemented excretory nitrogen to the soils. This would add an additional $88 \mathrm{~kg}$ if all excretion occurred in the riparian zone between foraging bouts. Gulls foraging in the

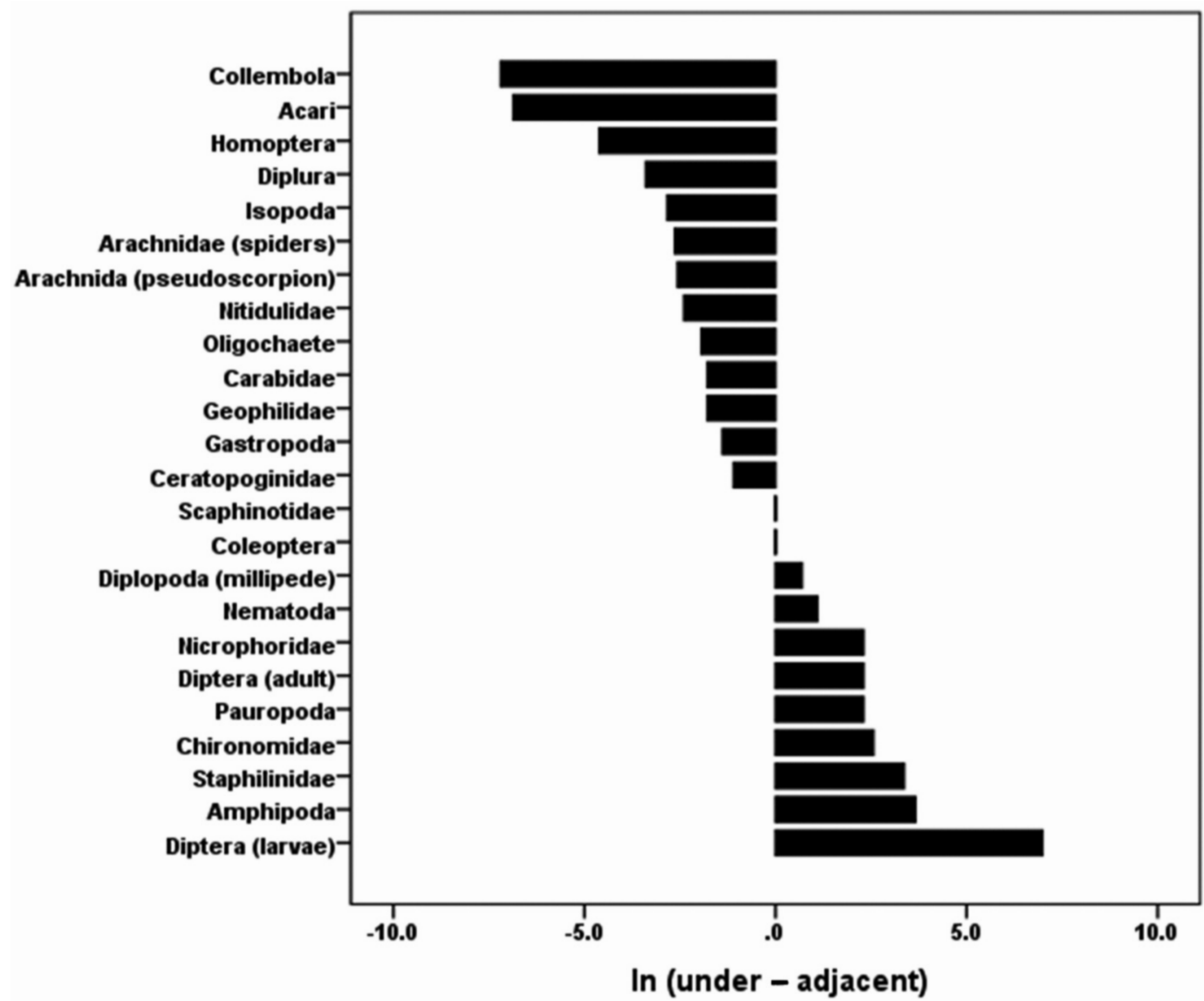

FIGURE 3. Differences in invertebrate diversity in paired soil plugs under and adjacent to Chum Salmon (Oncorhynchus keta) carcasses. All sites grouped. Data from October 2000. Bars show ln (number of individuals under carcass minus number of individuals adjacent to carcass). Values $>$ zero indicate greater abundance under carcass. 
stream channel could be observed resting on the stream banks and could supplement riparian nitrogen, but I will assume that the majority of their guano production took place in the stream channel, the estuary, or the headwater lake where gulls spent nights. Therefore, an upper range of nitrogen deposition to the $10 \mathrm{~m}$ riparian band along the $800 \mathrm{~m}$ of stream would be $405 \mathrm{~kg}$ or $20.9 \mathrm{~g} \mathrm{~N} / \mathrm{m}^{2}$.

\section{Nitrogen signatures in riparian plants}

Foliar $\delta^{15} \mathrm{~N}$ values were highly variable within each species (Lanky Moss, $n=88, \bar{x}=-0.89 \%$, range -10.4 to 9.9 ; Huckleberry, $n=41, \bar{x}=0.45 \%$, range -8.2 to 6.5 ; Salal, $n=88, \bar{x}=1.07 \%$, range -9.6 to 9.8 ; Western Hemlock, $n=97, \bar{x}=-0.81 \%$, range -8.3 to 7.2) with significant differences among the species $\left(F_{3,310}=5.4, P<0.001\right)$. This variation in isotopic values showed spatial structure across the riparian zone (Figure 4) with ${ }^{15} \mathrm{~N}$ depleted values in each species occurring at sites close to the estuary $(<200 \mathrm{~m})$, at sites greater than $1000 \mathrm{~m}$ upstream and also those at increased distances $(>50 \mathrm{~m})$ into the forests. Correspondingly, ${ }^{15} \mathrm{~N}$ was more enriched from 300 to $800 \mathrm{~m}$ upstream, concordant with the general stream distribution of spawning gravels but also with site-specific carcass presence or absence. Among the habitat variables, Carcass was a more significant predictor of $\delta^{15} \mathrm{~N}$ than
DistForest in three of the four species (Lanky Moss: Carcass $F_{1,85}=7.4, P<0.005$, Distforest $F_{1,85}=0.45$, $P=0.5$; Huckleberry: Carcass $F_{1,38}=1.53, P=0.22$, Distforest $F_{1,38}=3.64, P=0.06$; Salal: Carcass $F_{1,85}$ $=7.89, P<0.005$, Distforest $F_{1,85}=0.47, P=0.5$; Western Hemlock: Carcass $F_{1,94}=21.83, P<0.001$, Distforest $\left.F_{1,94}=5.10, P<0.03\right)$. I equalized means among the four species and plotted residuals for the combined data and this much larger dataset (Figure 5) shows clear spatial structure and carcass associations in isotopic enrichment (ANOVA: Carcass $F_{1,311}=24.2$, $P<0.001$; Distforest $\left.F_{1,311}=6.2, P<0.02\right)$.

Total foliar nitrogen $(\% \mathrm{~N})$ varied among species (Lanky Moss: $\bar{x}=0.91 \%$, range 0.5 to 1.8 ; Huckleberry: $\bar{x}=1.61$, range 0.7 to 2.3 ; Salal: $\bar{x}=1.02 \%$, range 0.7 to 2.1 ; Western Hemlock: $\bar{x}=1.11 \%$, range 0.5 to 2.3 ; ANOVA: $\left.F_{3,310}=49.6, P<0.001\right)$. In each of the species, $\% \mathrm{~N}$ was positively correlated with $\delta^{15} \mathrm{~N}$ (Lanky Moss: $r=0.39, P<0.01$; Huckleberry: $r=0.62, P<0.01$; Salal: $r=0.35, P<0.01$; Western Hemlock: $r=0.36, P<0.01)$. Scatterplots of $\delta^{15} \mathrm{~N}$ against $\% \mathrm{~N}$ separated for absence/presence of carcasses are shown in Figure 6. The paired slopes $(B)$ did not differ statistically from each other $(P>0.3$ for Huckleberry, Salal, and Western Hemlock although $P$ $=0.06$ for Lanky Moss). Multivariate GLM with $\delta^{15} \mathrm{~N}$

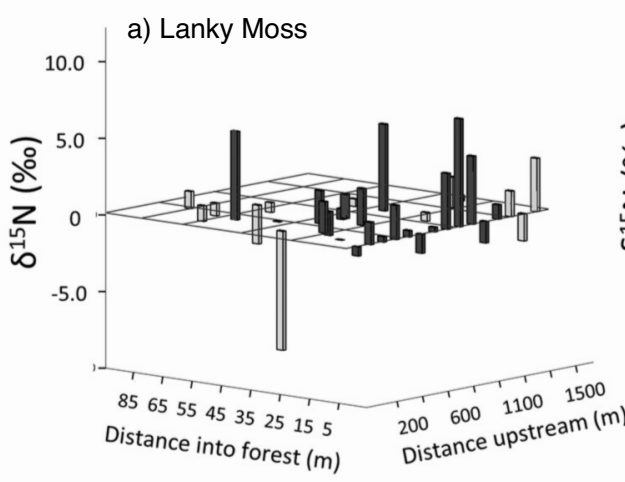

c) Salal

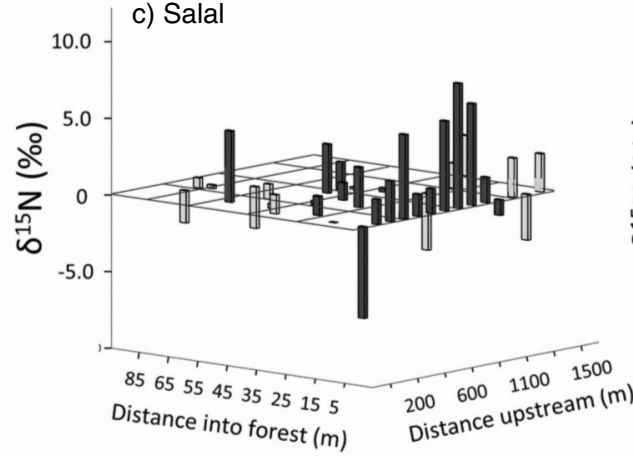

b) Huckleberry

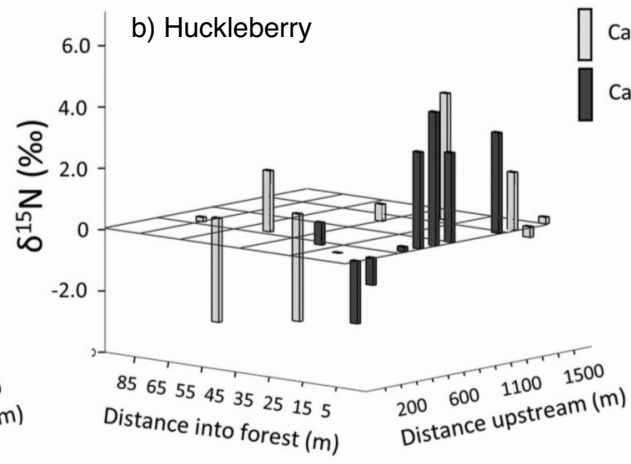

d) Western Hemlock

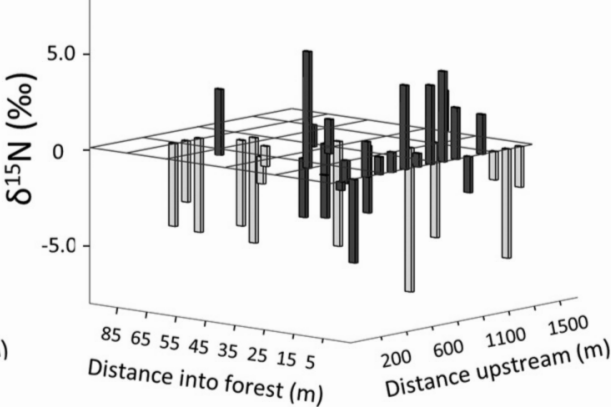

FIgURE 4. Average foliar nitrogen isotope values (\%) for riparian microsites separated by species. Note different scales for distance upstream and distance into the forest. False floor shows $0 \%$. 
and $\% \mathrm{~N}$ as dependents, and Carcass and DistForest as predictors (Table 2) yielded significant models for both dependents although the explained variance (partial eta $^{2}$ ) for the full models is low and usually between $10 \%$ and $30 \%$. However, in each species except Huckleberry, $\% \mathrm{~N}$ and $\delta^{15} \mathrm{~N}$ were significantly higher in sites where carcasses were present. Additionally, $\% \mathrm{~N}$ decreased into the forest for Lanky Moss while $\delta^{15} \mathrm{~N}$ decreased into the forest for Western Hemlock.

$\% \mathrm{MDN}$ in the foliar tissues varied with respect to species and microsite. It was lowest in Huckleberry $(\bar{x}=11.1 \%$, range $-67 \%$ to $60 \%)$, intermediate in Lanky Moss $(\bar{x}=13.6 \%$, range $-90 \%$ to $90 \%$ ) and in Salal ( $\bar{x}=16.6 \%$, range $-81 \%$ to $89 \%$ ), and highest in Western Hemlock ( $x=24.9 \%$, range $-32 \%$ to $73 \%$; $\left.F_{3,227}=2.5, P=0.06\right)$. Negative $\% \mathrm{MDN}$ values occurred when $\delta^{15} \mathrm{~N}$ values were lower than the control sites.

\section{Discussion}

Yearly migration of anadromous salmon (Oncorhynchus spp.) from the open ocean to coastal habitats of the North Pacific has great antiquity extending back at least 10000 years in northern latitudes (Pielou 1991) and up to 10 million years south of the ice fronts (Alex- androu et al. 2013). Despite the expanding recognition of the importance of this nutrient pulse to coastal ecosystems (Ben-David et al. 1998; Jauquet et al. 2003; reviews in Helfield and Naiman 2006; Johnson and Schindler 2009; Darimont et al. 2010), a characterization of a basic food web at the marine-terrestrial interface for a salmon spawning run has not been previously undertaken.

Estuarine congregations of gulls during salmon migration are well-known with their abundance generally proportional to total salmon spawning biomass (Field and Reynolds 2013). At two mainland estuaries, with salmon spawning runs of about 30000 and 50000 salmon, there were 2000 and 3500 gulls, respectively (6.5\% and $7.2 \%$ of salmon numbers) and these consumed $20 \%$ of the total post-reproductive salmon biomass in each locality (Christie and Reimchen 2006). At Bag Harbour, $100 \mathrm{~km}$ off the west coast of the mainland, gulls were also one of the dominant scavengers. During the 1992 and 1993 spawning runs, gull numbers were $8 \%$ and $6 \%$ of salmon numbers, respectively, and consumed $30 \%$ and $10 \%$ of the spawning biomass, respectively, broadly similar to mainland watersheds. This concentrated foraging by gulls on a largely unrestricted nutrient source over multiple weeks is probably

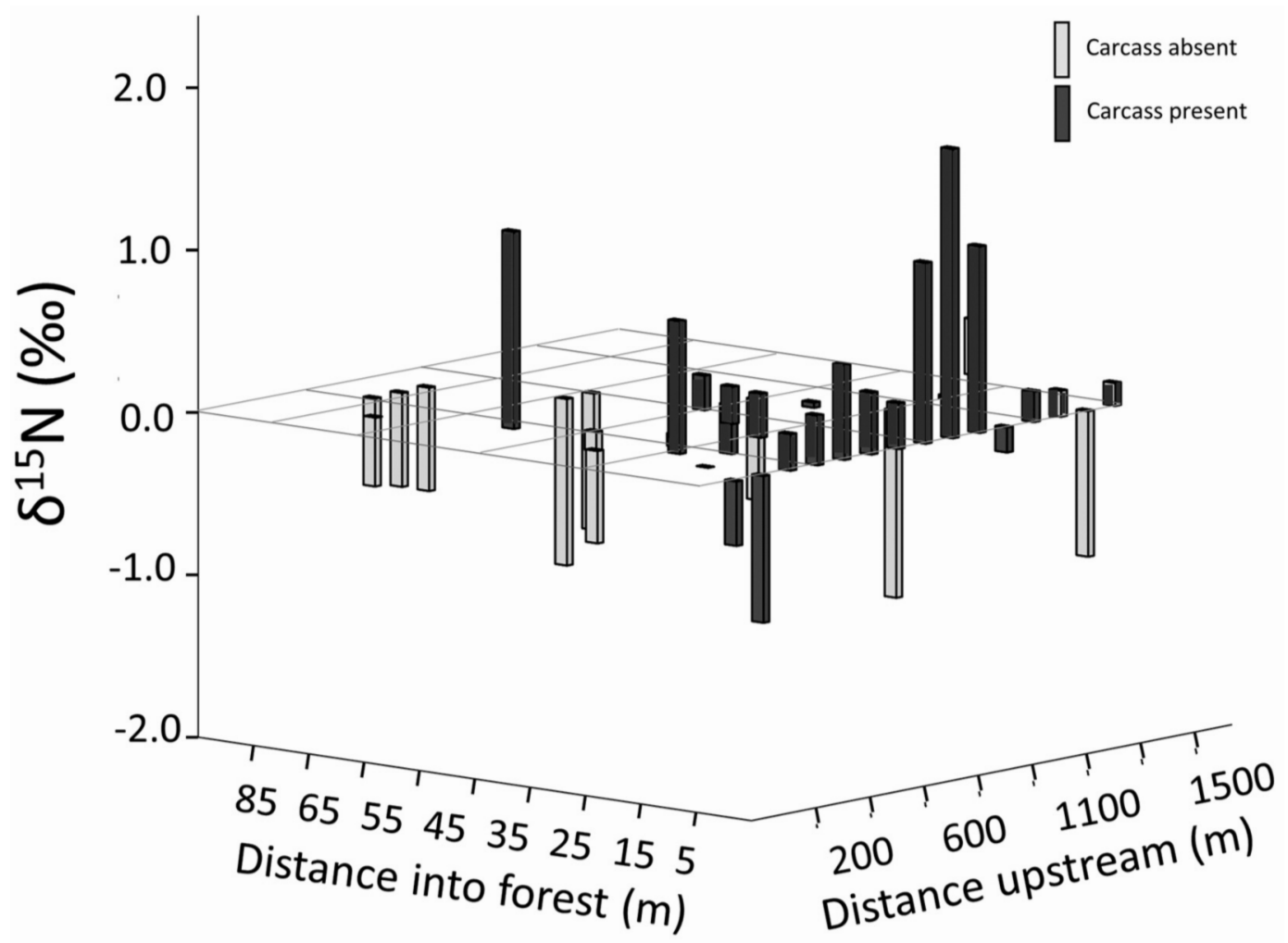

FIGURE 5. Average residual foliar nitrogen isotope values (\%) for riparian microsites with all species combined. Values represent residuals derived separately for each species. Note different scales for distance upstream and distance into the forest. False floor shows $0 \%$. 


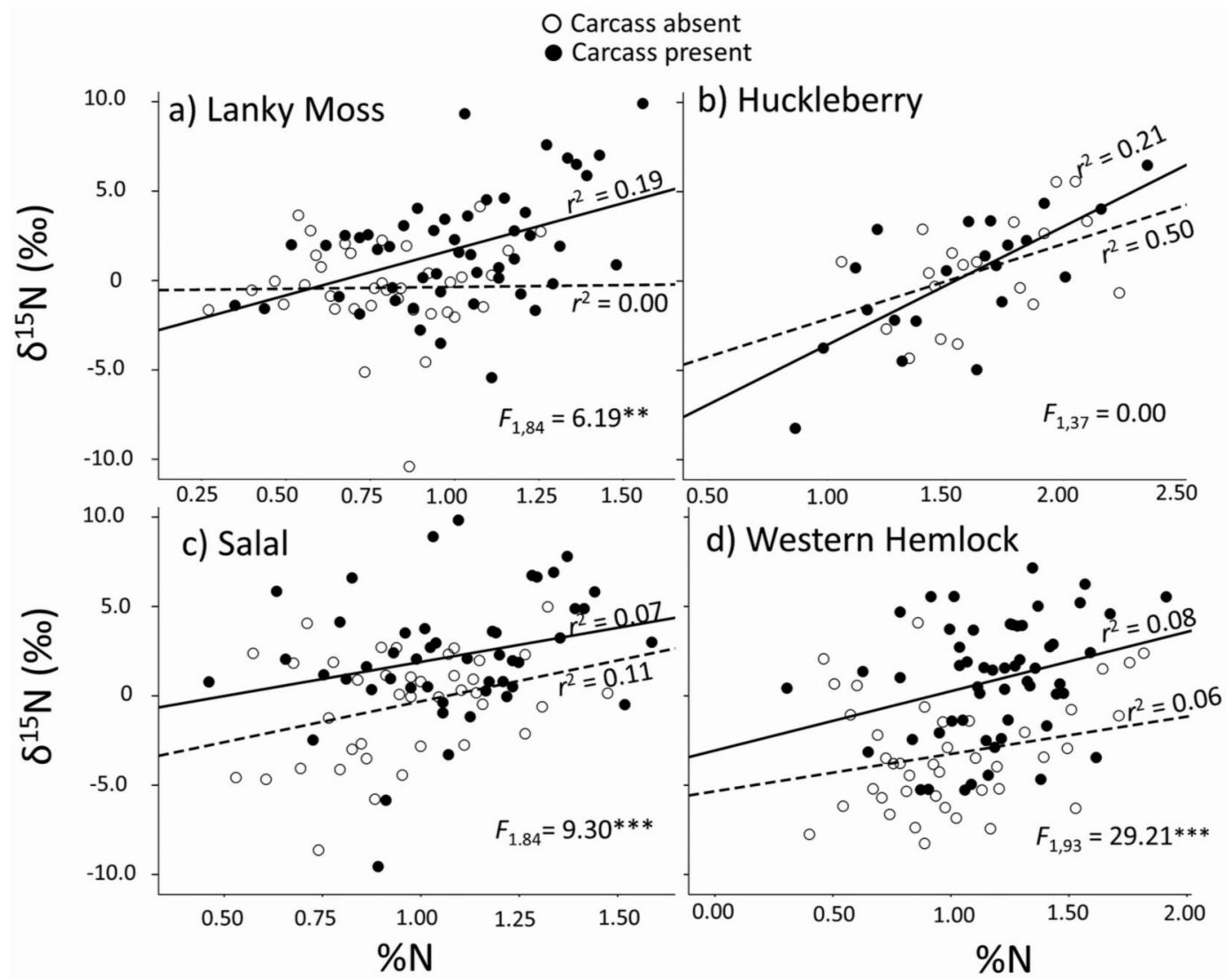

FIGURE 6. Associations between foliar $\delta^{15} \mathrm{~N}$ and percent nitrogen $(\% \mathrm{~N})$ for riparian taxa. Plots show $r^{2}$ and $F$ statistic for comparisons between the regression line marginal means for sites with Chum Salmon (Oncorhynchus keta) carcasses absent or present. The paired slopes did not differ statistically from each other $(P>0.3$ in Huckleberry [Vaccinium parvifolium], Salal [Gaultheria shallon], and Western Hemlock [Tsuga heterophyll] and $P=0.06$ in Lanky Moss [Rhytidiadelphus loreus] $).$ All \% $\mathrm{N}$ data are normalized using Box-Cox transformation (see Methods). $* * * P<0.001$ ** $P<0.01$.

of considerable importance. As in many marine birds, food constraints are common during their life history, particularly during winter (Lack 1966; Coulter 1975), so it is likely that the geographical distribution of salmon spawning runs in addition to the biomass of each run will influence gull life histories throughout the north Pacific. The serendipitous observation of multiple gull carcasses cached beneath trees by resident marten extends the trophic linkages of the gull aggregations.

The extent of salmon carcass consumption by estuarine subtidal scavengers has received limited attention. Large decapods such as the Dungeness Crab (Cancer magister) and Red-rock Crab are geographically widespread scavengers (Thorne et al. 2006). But while present in Bag Harbour estuary, Dungeness Crab were not observed on carcasses. Such absence might reflect the low tissue quality of senescent carcasses (Winder et $a l$.2005) or possibly that they were more active during darkness rather than daylight when I surveyed (e.g., McGaw 2005). At Bag Harbour, $3700 \mathrm{~kg}$ of salmon biomass was washed into the estuary and the major sca- vengers I observed in shallow depths were gastropods and species of hermit crab with prawns and echinoderms at greater depths. High densities of these scavengers on the carcasses may be an important trophic link in productivity and diversity in estuaries. Fujiwara and Highsmith (1997) identified a positive feedback loop in which the downstream accumulation of salmon carcasses in estuaries increased nitrates and phosphates that stimulated growth of the macrophyte Ulva. Ulva, in turn, was the major food of harpacticoid copepods, the latter comprising an important prey of juvenile salmon. As well, watershed size and salmon density were positively associated with growth responses in estuarine intertidal bivalves (Harding et al. 2015). Cak et al. (2008) also found estuarine increases in nutrients from salmon carcasses, but without effects on primary productivity. During my SCUBA surveys at Bag Harbour, full dissolution of the carcasses into the estuarine water column occurred after 5-7 days of submergence that would have increased organic carbon, nitrates, and phosphates. The partially restricted tidal entrance to 
TABLE 2. Multivariate general linear model for foliar $\delta^{15} \mathrm{~N}$ and foliar $\% \mathrm{~N}$ using Chum Salmon (Oncorhynchus keta) Carcass (absence/presence) as a fixed factor and DistForest as covariate for riparian species in Bag Harbour, British Columbia. Source (Model, Carcass, Distforest) shows slope $( \pm$ ) of regression line. Model represents the corrected model. All significant results are shown in bold.

\begin{tabular}{|c|c|c|c|c|c|}
\hline Species & Dependent & Source & $F_{\mathrm{df}}$ & $P$ & Partial eta $^{2}$ \\
\hline Lanky Moss & $\begin{array}{c}\delta^{15} \mathbf{N} \\
\% \mathbf{N}\end{array}$ & $\begin{array}{l}\text { Model+ } \\
\text { Carcass+ } \\
\text { DistForest- } \\
\text { Model+ } \\
\text { Carcass+ } \\
\text { DistForest- }\end{array}$ & $\begin{array}{r}\mathbf{5 . 9 7} \\
\mathbf{7 . 1 8 4} \\
0.40_{1,84} \\
12.51_{2,84} \\
\mathbf{5 . 5 8}_{1,84} \\
\mathbf{7 . 5 1}_{1,84}\end{array}$ & $\begin{array}{l}0.004 \\
0.009 \\
0.530 \\
0.000 \\
0.020 \\
0.008\end{array}$ & $\begin{array}{l}0.12 \\
0.08 \\
0.01 \\
0.23 \\
0.06 \\
0.08\end{array}$ \\
\hline Huckleberry & $\begin{array}{l}\delta^{15} \mathrm{~N} \\
\% \mathrm{~N}\end{array}$ & $\begin{array}{l}\text { Model+ } \\
\text { Carcass- } \\
\text { DistForest- } \\
\text { Model+ } \\
\text { Carcass- } \\
\text { DistForest- }\end{array}$ & $\begin{array}{l}1.86_{2,37} \\
1.69_{1,37} \\
3.52_{1,37} \\
0.88_{2,37} \\
1.45_{1,37} \\
1.13_{1,37}\end{array}$ & $\begin{array}{l}0.170 \\
0.200 \\
0.070 \\
0.430 \\
0.240 \\
0.300\end{array}$ & $\begin{array}{l}0.09 \\
0.04 \\
0.09 \\
0.05 \\
0.04 \\
0.03\end{array}$ \\
\hline Salal & $\delta^{15} \mathrm{~N}$ & $\begin{array}{l}\text { Model+ } \\
\text { Carcass+ } \\
\text { DistForest- } \\
\text { Model+ } \\
\text { Carcass+ } \\
\text { DistForest+ }\end{array}$ & $\begin{array}{r}\mathbf{6 . 9 8}_{\mathbf{2 , 8 7}} \\
\mathbf{1 0 . 6 9}_{\mathbf{1 , 8 7}} \\
0.08_{1,87} \\
\mathbf{4 . 6 7}_{\mathbf{2 , 8 7}} \\
\mathbf{8 . 7 6}_{1,87} \\
3.72_{1,87}\end{array}$ & $\begin{array}{l}\mathbf{0 . 0 0 2} \\
\mathbf{0 . 0 0 2} \\
0.790 \\
\mathbf{0 . 0 1 2} \\
\mathbf{0 . 0 0 4} \\
0.060\end{array}$ & $\begin{array}{l}\mathbf{0 . 1 4} \\
\mathbf{0 . 1 1} \\
0.00 \\
\mathbf{0 . 1 0} \\
\mathbf{0 . 0 9} \\
0.04\end{array}$ \\
\hline Western Hemlock & $\delta^{15} \mathbf{N}$ & $\begin{array}{l}\text { Model+ } \\
\text { Carcass+ } \\
\text { DistForest- } \\
\text { Model+ } \\
\text { Carcass+ } \\
\text { DistForest+ }\end{array}$ & $\begin{array}{r}22.83_{2,93} \\
\mathbf{2 0 . 7 2}_{1,93} \\
\mathbf{5 . 3 8}_{1,93} \\
\mathbf{5 . 9 5}_{\mathbf{2 , 9 3}} \\
11.7 \mathbf{1}_{1,93} \\
3.882_{1,93}\end{array}$ & $\begin{array}{l}\mathbf{0 . 0 0 0} \\
\mathbf{0 . 0 0 0} \\
\mathbf{0 . 0 2 3} \\
\mathbf{0 . 0 0 4} \\
\mathbf{0 . 0 0 1} \\
0.052\end{array}$ & $\begin{array}{l}\mathbf{0 . 3 3} \\
\mathbf{0 . 1 8} \\
\mathbf{0 . 0 6} \\
\mathbf{0 . 1 1} \\
\mathbf{0 . 1 1} \\
0.04\end{array}$ \\
\hline
\end{tabular}

Bag Harbour (see Figure 1) would limit the daily mixing of tidal waters that would extend the duration of nutrients and benefits to productivity and may have contributed to the high densities of schooling fish and avian piscivores during, and after, the spawning run.

In stream channels, salmon nutrients make significant contributions to primary productivity (Cederholm et al. 1989; Thomas et al. 1999), to diversity and abundance of aquatic invertebrate scavengers (Nakajima and Ito 2003; Quamme and Slaney 2003; Wipfli et al. 2003), and to juvenile salmonid production (Bilby et al. 1996; Slaney et al. 2003; review in Stockner and Ashley 2003). This is in addition to their direct use by predators such as bears, wolves, marten, and birds (Ben-David et al. 1997; Cederholm et al. 1999; Hilderbrand et al. 1999; Klinka and Reimchen 2002, 2009; Darimont et al. 2003). In each year of my study, throughout much of the $800 \mathrm{~m}$ of the stream spawning areas, large flocks of gulls and crows were active throughout the day while bears occurred throughout daylight and darkness (Reimchen 1998). Aquatic invertebrate scavengers were not dominant in Bag Harbour stream channel during my study. Many of the senescent carcasses that accumulate in pools and are typically exploited by these scavengers had low residence time during my study as carcasses were usually swept downstream into the estuary by the high water flows. This would limit the contribution to both primary and invertebrate scavenger productivity during high flow years.

Predator-mediated uploading of salmon carcasses to the riparian zone and their use by scavengers was first systematically documented in the Olympic Peninsula, western Washington, by Cederholm et al. (1989). My studies at Bag Harbour, Haida Gwaii, broadened the evidence for the major contribution of bears in such uploading (Reimchen 1992, 1994, 2000), while independent studies in coastal Alaska show a major role of Grizzly Bear (Ursus arctos) in the transfer of salmon nutrients to riparian zones (Hilderbrand et al. 1999, 2004; Gende et al. 2004). Although more limited in their effect, other predators such as Gray Wolf (Canis lupus), marten, and avian scavengers including gulls and eagles can be locally important in some watersheds (Ben-David et al.1997; Darimont et al. 2003; Christie and Reimchen 2006). Flooding during heavy rainfall can also have an effect in low gradient watersheds (Ben-David et al. 1998; Bilby et al. 2003).

Despite the ecological importance of the contribution of salmon to riparian zones, the densities of riparian carcasses have not been previously quantified in studies of the marine-terrestrial interface. Data for Bag Harbour demonstrate an average occurrence of 2.3 carcasses per linear metre on each side of the stream, or approximately one carcass per 5 square metres in the $10 \mathrm{~m}$ wide 
riparian band. While scavengers such as crows and marten exploited this resource, the principal consumers of the soft tissues were dipteran larvae. In 1993, 95\% of the carcasses were fully enveloped in dipteran larvae resulting in consumption of most tissues. Published estimates of total dipteran larvae per carcass vary from 4000 to 29000 (Goodbrod and Goff 1990; Hocking and Reimchen 2002; Meehan et al. 2005). I used the most conservative of these values and this predicts the total abundance of 15 million larvae in the Bag Harbour riparian zone or approximately $740 / \mathrm{m}^{2}$. Soil plugs extracted from multiple microsites yielded 24 invertebrate taxa, including predatory arthropods such as staphylinid and carabid beetles that would exploit both larvae and pupae (e.g., Allen and Hagley 1990; Hocking and Reimchen 2002). Recent studies on mainland watersheds indicate a rich assemblage of 60 invertebrate species including a diversity of Diptera, predatory beetles, and predatory wasps directly or indirectly associated with salmon carcasses (Hocking and Reimchen 2006; Hocking et al. 2009; Juen and Tragott 2007). Such diversity benefits vertebrate insectivores (Jauquet et al. 2003; Christie and Reimchen 2008; Christie et al. 2008).

Riparian densities of calliphorid larvae differed dramatically between sequential years. Larvae were not observed on any of the $800+$ riparian carcasses observed in autumn 1992 yet these dominated the majority of carcasses in autumn 1993 (Figure 2). This large yearly difference was unexpected for an intact old growth forest because the major ecological players (salmon, bears, Diptera) were present each year of the study. While there could be cyclicity in calliphorid population trends, I suspect the yearly effects are due to temperature and insect flight activity. Average October daytime air temperatures for Bag Harbour (extracted from the closest Environment Canada meteorological station at Sandspit, British Columbia) were $5.6^{\circ} \mathrm{C}$ in 1992 and $9.2^{\circ} \mathrm{C}$ in 1993 while lowest daytime temperatures were $2.0^{\circ} \mathrm{C}$ and $7.5^{\circ} \mathrm{C}$, respectively. Relative flight activity of large dipterans as well as larval development is greatly reduced below $10^{\circ} \mathrm{C}$ (Chappell and Morgan 1987; Heaton et al. 2014) and could be the principal cause for the lack of egg production of the dipterans during the low 1992 temperatures. Such covariation between yearly autumn temperatures and trophic associations in the riparian zone suggests broader geographical trends among salmon watersheds from southern and northern latitudes or among salmon species that spawn at different times of the year. It also implies microspatial heterogeneity in trophic associations with sun exposure and temperature regime of individual carcasses. For example, salmon carcasses abandoned by bears in shaded areas of the riparian zone (i.e., shaded side of a tree trunk) would be less likely to receive visits from egg-laying dipterans and these carcasses would have extended use by vertebrate scavengers. Comparable trends in development rate have been observed in experimental forensic studies with blowfly larvae on shaded and unshaded pig carcasses (Shean et al. 1993). Such heterogeneity might contribute to the large differences in isotopic values among microsites in the riparian zones in this study, a trend also seen in microgeographical differences in isotopic signatures of bryophytes of mainland salmon watersheds (Wilkinson et al. 2003) as well as soil nitrogen signatures in riparian zones of Alaskan salmon rivers (Holtgrieve et al. 2009).

Estimates of salmon-derived nitrogen subsidies to riparian soils from predator and scavenger activity in the northeast Pacific are highly variable within and among watersheds. Based on salmon consumption rates by Alaskan Brown Bears (= Grizzly Bears), nitrogen contributions to the riparian soils were estimated at $0.005 \mathrm{~g} \mathrm{~N} / \mathrm{m}^{2}$, of which $97 \%$ is added via urine (Hilderbrand et al. 1999). Gende et al. (2007), also investigating Alaskan Brown Bears, calculated contributions of $1.4 \mathrm{~g} \mathrm{~N} / \mathrm{m}^{2}$ to $10.5 \mathrm{~g} \mathrm{~N} / \mathrm{m}^{2}$ in a riparian band immediately adjacent to the salmon stream. Recent experimental evidence involving bear exclusion zones indicate substantive deficiencies in soil nitrogen processing compared with sites with bear activity (Holtgrieve et al. 2009). For the Bag Harbour watershed, I have incorporated carcass, bear and avian activity as well as invertebrate sources and estimate an average input of $18.8 \mathrm{~g}$ $\mathrm{N} / \mathrm{m}^{2}$ within a $10 \mathrm{~m}$ band of the stream and a $1.12 \mathrm{~g}$ $\mathrm{N} / \mathrm{m}^{2}$ at greater distances $(10-50 \mathrm{~m})$ along the riparian zone adjacent to the $800 \mathrm{~m}$ length of spawning gravels. If these groups were distributed uniformly over the entire riparian area $(0-50 \mathrm{~m}$ band) rather than predominantly within the $10 \mathrm{~m}$ band where most of the carcasses, faeces, and scavenger activity were observed, then average nitrogen input would be $4.7 \mathrm{~g} \mathrm{~N} / \mathrm{m}^{2}$, which is about three to 30 times higher than those observed for Alaskan Brown Bears. Atmospheric nitrogen fixers such as Red Alder (Alnus rubra Bongard) are also sources of the soil nitrogen pool in coastal riparian zones with yearly fixation ranging from $3.5 \mathrm{~g} \mathrm{~N} / \mathrm{m}^{2}$ to $13.0 \mathrm{~g} \mathrm{~N} / \mathrm{m}^{2}$ (Binkley 1982). Alder is uncommon in the riparian zone at Bag Harbour watershed and as such, my estimates from the uploading of salmon nutrients by Black Bears over the eight weeks are equivalent to that of the yearly nitrogen fixation for a pure stand of Red Alder. Other limiting nutrients, such as phosphorus, that can constrain plant growth in coastal forests (Blevins et al. 2006), would also be supplemented with the salmon carcasses. Some of this riparian soil nitrogen could be lost due to groundwater movement and hyporheic flow into the stream and estuary (O'Keefe and Edwards 1993; Ben-David et al. 1997) although meta-analysis of attenuation rates indicates high nitrogen retention in undisturbed riparian zones, particularly in watersheds with low relief (Ranalli and Macalady 2010), which is the case for Bag Harbour.

The last three decades have seen a major expansion of stable isotope techniques in ecological studies (Fry 2006) including the identification of marine-derived nitrogen in foliar tissues of riparian habitats adjacent 
to salmon rivers (e.g., Ben-David et al. 1998; Hilderbrand et al. 1999; Bilby et al. 2003; Reimchen et al. 2003; Nagasaka et al. 2006; Naiman et al. 2009). However, numerous processes can result in ${ }^{15} \mathrm{~N}$ enrichment in foliar tissues including increased annual temperature, reduced rainfall, increased root depth, reduction in mycorrhizal fungi, and increased soil nitrogen availability (Craine et al. 2009, 2012, 2015), each of which can potentially produce false signals of marine-derived nitrogen sources in vegetation. Paired sampling across sharp ecological gradients in salmon carcass density (Mathewson et al 2003; Wilkinson et al. 2005; Reimchen and Fox 2013), in bear activity zones (Hilderbrand et al. 1999) as well as experimental addition of salmon carcasses to virgin sites (Hocking and Reynolds 2012) provide improved confidence in interpreting nitrogen isotope signatures and sources. My study showed that higher isotopic ratios occurred in zones of high carcass density and bear foraging activity close to the spawning gravels and that ratios were reduced at greater distances into the forest where carcasses were absent and bear activity reduced. Although this is suggestive of a causal relationship, such a riparian isotopic gradient also occurs in Alaska streams without salmon and reflects denitrification (and subsequent enrichment) in the soils adjacent to streams (Bilby et al. 2003). This could be contributory to the gradient I observed but given that enrichment occurs at replicated carcass sites and depletion at adjacent non-carcass sites, the differences in ratios are consistent with the proximal effects of carcasses rather than effects of denitrification. Furthermore, the greatest reduction in $\delta^{15} \mathrm{~N}$ occurred near the upper reaches of the spawning gravels across a sharp gradient in carcass density yet within the same narrow riparian band adjacent to the stream. Comparable sharp isotopic differentiation in multiple riparian herbs and shrubs occurred on mainland watersheds immediately below and above waterfall barriers to salmon migration (Mathewson et al. 2003), as well as among bryophytes separated by several meters on and off bear trails (Wilkinson et al. 2005).

Among the four plant species I examined at Bag Harbour, isotopic values among microsites ranged from a minimum of $-10.4 \%$ to a maximum of $9.9 \%$. In an assessment of ${ }^{15} \mathrm{~N}$ variability of multiple plant taxa from a diversity of geographical latitudes, temperatures, precipitation, and edaphic conditions, Craine et al. (2015) found that $95 \%$ of the isotopic data ranged between $-7.8 \%$ and $8.7 \%$. As such, even when factoring in the positive relationship between sample size and isotopic range (Craine et al. 2009), the Bag Harbour data equal or exceed the maximum range observed in the global survey. This high microsite variability cannot be due to taxonomic bias as it occurred in each taxa including a bryophyte, two ericads, and a gymnosperm. This variability is probably representative of the level of microspatial heterogeneity in edaphic conditions, including nitrogen availability that may differentiate salmon watersheds from non-salmon watersheds.
Estimates of the relative contribution of marinederived nutrients (\%MDN) depend on geography and taxonomy but tend to vary from $10 \%$ to $30 \%$, with occasional higher values (Bilby et al. 1996, 2003; Hilderbrand et al. 1999; Helfield and Naiman 2001; Mathewson et al. 2003). I estimated that \%MDN averaged $18 \%$ at Bag Harbour with maximum estimates for individual plants of $60 \%$ in Huckleberry to $89 \%$ in Lanky Moss and Salal. Such high estimates have been reported for individual growth rings in Sitka Spruce from this location (Reimchen and Fox 2013), as well as from shrubs in high salmon density watersheds on the British Columbia mainland (Mathewson et al. 2003). However, I suspect that true estimates at Bag Harbour could be even higher, due to two factors. Firstly, for a terrestrial end member for each species, I used ${ }^{15} \mathrm{~N}$ values from plants collected above the upper distribution of spawning gravels as well as those distant into the forest beyond the outer distribution of salmon carcasses. Yet even in such 'control' sites, there was possible input of guano from flocks of crows or urine from bears moving through the sites. As such, the samples would be enriched relative to a 'true' control site resulting in lower $\%$ MDN estimates. Moving greater distances away from the stream to minimize such occasional nutrient influences increases the confounding impacts of the multiple abiotic and mycorrhizal associations known to influence nitrogen isotope ratios in plants (Craine et al. 2009). Secondly, artificially low estimates are indicated by the occasional negative \%MDN where foliar ${ }^{15} \mathrm{~N}$ values are less than the control. As these negative values occurred at sites with very high bear activity, I suspect that these soils were nitrogen saturated. Plants will discriminate against ${ }^{15} \mathrm{~N}$ when nitrogen supply exceeds requirements and as a result, foliar tissues will be depleted in the heavy isotope (Nadelhoffer and Fry 1994). This implies that the extent of isotopic enrichment should scale positively with the relative loading of salmon-derived nutrients when the supply of nitrogen is less than that required by the plants but then scale negatively (increased fractionation) as the supply begins to exceed requirements (see Bilby et al. 2003; Hocking and Reimchen 2009; Hocking and Reynolds 2011). Most forests around the north Pacific are nitrogen-limited (Waring and Franklin 1979; Littke et al. 2014) but when large allochthonous nitrogen pulses occur, as in the bear-mediated uploading of salmon nutrients, surplus nitrogen is possible. Consequently, estimates of \%MDN based on the absolute values of $\delta^{15} \mathrm{~N}$ in relation to a TEM, will greatly underestimate $\% \mathrm{MDN}$ when nitrogen supplies to specific microsites exceed requirements. Such fractionation against ${ }^{15} \mathrm{~N}$ should occur particularly for seedlings and small shrubs where surplus loading is possible. In large trees, nitrogen surplus would rarely occur. One would also predict that if the soil is nitrogen saturated, there would be elevated $\% \mathrm{~N}$ in the tissues. The elevated $\% \mathrm{~N}$ that I detected occurred in three of the four plant species collected in the high bear activity zones close to the estuary. 
Does this input of salmon-derived nutrients increase riparian primary productivity? Such a positive effect could be expected given that most forests around the north Pacific are nitrogen limited (Waring and Franklin 1979). Enhanced growth rates in the riparian zone have been shown for Sitka Spruce in Alaska (Helfield and Naiman 2001) and at Bag Harbour, where there were significant positive growth responses in microsites where carcasses were prevalent and in years when spawning runs were elevated (Reimchen and Fox 2013). Foliar $\% \mathrm{~N}$ is also a proxy for primary production because a doubling of foliar nitrogen results in a $50 \%$ increase in chlorophyll content (Yoder and Pettigrew-Crosby 1995), which is itself directly correlated with primary productivity both for canopy and under-canopy habitats (Dawson et al. 2003). Craine et al. (2012) observed that foliar $\delta^{15} \mathrm{~N}$ and $\% \mathrm{~N}$ in many species are positively correlated with each other across broad geographical areas, independent of marine associations, and that both are elevated where soil nitrogen levels are high. In each plant species in my study, there was also a significant positive relationship between $\delta^{15} \mathrm{~N}$ and $\% \mathrm{~N}$. Higher values for both proxies occurred in the highest carcass transfer zones suggesting a direct increase in primary productivity in the high bear activity sites.

My observations at Bag Harbour on estuarine, stream, and riparian movement of salmon biomass, bear transfer, scavenger diversity, and nitrogen uptake by riparian vegetation are taxonomically and trophically more detailed than previous studies and are probably representative for an intact watershed from current time periods. Yet numbers of returning salmon in 1993, when most detailed field data were obtained, were approximately one-half the yearly average (10000) and onesixth the maximum (35000) number of salmon returning to this watershed between 1947 and 2000 (Marshall et al. 1978; Reimchen 1994). Further, these greater numbers in the recent past may seriously underestimate numbers from the late 1800 s prior to the expansion of the commercial fishing industry (Gresh et al. 2000). Developing restoration targets for compromised habitats is facilitated with insight on the 'pre-disturbance' state but for much of the globe, ecological baselines have not been identified. This deficiency is confounded by expanding anthropogenic influences on all aquatic and terrestrial ecosystems that result in continuously shifting baselines that further limits the identification of pre-disturbance states using present day habitats (Arcese and Sinclair 1997). Even in wellstudied taxa such as the great herds of African ungulates or the immense schools of marine clupeids, prehistorical densities are either unknown or at best interpolated (e.g., Finney et al. 2002).

Restoration of degraded stream and riparian habitats is an important component of reclamation in the Pacific Northwest (Lackey 2003). An overview of restoration practices for the western United States (Kauffman et al. 1997; Slaney and Martin 1997) examined the importance of salmon to stream habitats but failed to address their role in riparian habitats, presumably because such information was still poorly known. However, during the last 20 years, multiple studies have identified the major contributions of salmon nutrients to riparian habitats and the resulting trophic cascades on species diversity and productivity. Yet, despite this accumulating evidence, a recent synthesis and development of policy guidelines for the restoration of stream and riparian habitats in the Columbia River basin (Rieman et al. 2015) again excludes assessment of carcasses in the riparian zone. The current study at Bag Harbour provides empirical data on carcass densities, their scavengers, and total nitrogen input that can inform ecological baselines and restoration targets.

\section{Acknowledgements}

I thank Colin French, Doug Burles, Bristol Foster, Peter Mylechrest, Todd Golumbia, Deanna Mathewson, Leigh-Anne Isaac, Hana Hermanuk, and Crystal Rausch for field assistance, multiple lab volunteers for stable isotope preparation of plant samples, Neville Winchester and Richard Ring for insect identification, Carolyn Bergstrom and Caroline Fox for statistical comments, Peter Olesiuk and Graham Ellis (Fisheries and Oceans Canada) for data on pinniped daily food consumption, and Sheila Douglas and Barbara Hawkins for discussion and comments on the manuscript. I acknowledge the Council of the Haida Nation for permission to undertake this research in their territories. This research was initially funded by Parks Canada, subsequently by the David Suzuki Foundation and an NSERC operating grant to the author (NRC 2354).

\section{Literature Cited}

Alexandrou, M. A., B. A. Swartz, N. J. Matzke, and T. H. Oakley. 2013. Genome duplication and multiple evolutionary origins of complex migratory behavior in Salmonidae. Molecular Phylogenetics and Evolution 69: 514-523. https: //doi.org/10.1016/j.ympev.2013.07.026

Allen, W. R., and E. A. C. Hagley. 1990. Epigeal arthropods as predators of mature larvae and pupae of the apple maggot (Diptera: Tephritidae). Environmental Entomology 19: 309-312. https://doi.org/10.1093/ee/19.2.309

Arcese, P., and A. R. E. Sinclair. 1997. The role of protected areas as ecological baselines. Journal of Wildlife Management 61: 587-602. https://doi.org/10.2307/3802167

Banner, A., W. H. MacKenzie, J. Pojar, A. MacKinnon, S. C. Saunders, and H. Klassen. 2014. A field guide to ecosystem classification and identification for Haida Gwaii. B.C. Land Management Handbook 68. Province of British Columbia, Victoria, British Columbia, Canada. Accessed 14 March 2018. http://www.for.gov.bc.ca/hfd/pubs/ Docs/Lmh/Lmh68.htm.

Ben-David, M., R. W. Flynn, and D. M. Schell. 1997. Annual and seasonal changes in diets of martens: evidence from stable isotope analysis. Oecologia 111: 280-291. https:// doi.org/10.1007/s004420050236

Ben-David, M., T. A. Hanley, and D. M. Schell. 1998. Fertilization of terrestrial vegetation by spawning Pacific salmon: 
the role of flooding and predator activity. Oikos 83: 47-55. https://doi.org/10.2307/3546545

Bilby, R. E., E. W. Beach, B. R. Fransen, J. K. Walter, and P. A. Bisson. 2003. Transfer of nutrients from spawning salmon to riparian vegetation in western Washington. Transactions of the American Fisheries Society 132: 733-745. https://doi.org/10.1577/T02-089

Bilby, R. E., B. R. Fransen, and P. A. Bisson. 1996. Incorporation of nitrogen and carbon from spawning coho salmon into the trophic system of small streams: evidence from stable isotopes. Canadian Journal of Fisheries and Aquatic Sciences 53: 164-173. https://doi.org/10.1139/cjfas-53$1-164$

Binkley, D. 1982. Nitrogen-fixation and net primary production in a young Sitka alder stand. Canadian Journal of Botany 60: 281-284. https://doi.org/10.1139/b82-036

Birtfriesen, V. L., W. A. Montevecchi, D. K. Cairns, and S. A. Macko. 1989. Activity-specific metabolic rates of freeliving northern gannets and other seabirds. Ecology 70: 357-367. https://doi.org/10.2307/1937540

Blevins, L. L., C. E. Prescott, and A. Van Niejenhuis. 2006. The roles of nitrogen and phosphorus in increasing productivity of western hemlock and western redcedar plantations on northern Vancouver Island. Forest Ecology and Management 234: 116-122. https://doi.org/10.1016/j.foreco. 2006.06.029

Cak, A. D., D. T. Chaloner, and G. A. Lamberti. 2008. Effects of spawning salmon on dissolved nutrients and epilithon in coupled stream-estuary systems of southeastern Alaska. Aquatic Sciences 70: 169-178. https://doi.org/ 10.1007/s00027-008-8090-5

Cederholm, C. J., D. B. Huston, D. L. Cole, and W. J. Scarlett. 1989. Fate of coho salmon (Oncorhynchus kisutch) carcasses in spawning streams. Canadian Journal of Fisheries and Aquatic Sciences 46: 1347-1355. https://doi.org/ 10.1139/f89-173

Cederholm, C. J., D. H. Johnson, R. E. Bilby, L. G. Dominguez, A. M. Garrett, W. H. Graeber, E. L. Greda, M. D. Kunze, B. G. Marcot, J. F. Palmisano, R. W. Plotnikoff, W. G. Pearcy, C. A. Simenstad, and P. C. Trotter. 2000. Pacific salmon and wildlife-ecological contexts, relationships, and implications for management. Special edition technical report. Wildlife-habitat relationships in Oregon and Washington. Washington Department of Fish and Wildlife, Olympia, Washington, USA.

Cederholm, C. J., M. D. Kunze, T. Murota, and A. Sibatani. 1999. Pacific salmon carcasses: essential contributions of nutrients and energy for aquatic and terrestrial ecosystems. Fisheries 24: 6-15. https://doi.org/10.1577/15488446(1999)024<0006:PSC $>2.0 . \mathrm{CO} ; 2$

Chappell, M. A., and K. R. Morgan. 1987. Temperature regulation, endothermy, resting metabolism, and flight energetics of tachinid flies (Nowickia sp.). Physiological Zoology 60: 550-559.

Christie, K. S., M. D. Hocking, and T. E. Reimchen. 2008. Tracing salmon-derived nutrients in riparian foodwebs: isotopic evidence in a ground-foraging passerine. Canadian Journal of Zoology 86: 1317-1323. https://doi.org/10.1139/ Z08-110

Christie, K. S., and T. E. Reimchen. 2006. Post-reproductive Pacific salmon as a major nutrient source for large aggregations of gulls. Canadian Field-Naturalist 119: 202-207. https://doi.org/10.22621/cfn.v119i2.107

Christie, K. S., and T. E. Reimchen. 2008. Presence of salmon increases passerine density on Pacific North-west streams. Auk 125: 51-59. https://doi.org/10.1525/auk.2008. 125.1.51

Coulter, M. C. 1975 . Post-breeding movements and mortality in the Western Gull, Larus occidentalis. Condor 77: 243249. https://doi.org/10.2307/1366220

Craine, J. M., E. N. J. Brookshire, M. D. Cramer, N. J. Hasselquist, K. Koba, E. Marin-Spiotta, and L. Wang. 2015. Ecological interpretations of nitrogen isotope ratios of terrestrial plants and soils. Plant and Soil 396: 1-26. https://doi.org/10.1007/s11104-015-2542-1

Craine, J. M., A. J. Elmore, M. P. M. Aidar, M. Bustamante, T. E. Dawson, E. A. Hobbie, A. Kahmen, M. C. Mack, K. K. McLauchlan, A. Michelsen, G. B. Nardoto, L. H. Pardo, J. Peñuelas, P. B. Reich, E. A. G. Schuur, W. D. Stock, P. H. Templer, R. A. Virginia, J. M. Welker, and I. J. Wright. 2009. Global patterns of foliar nitrogen isotopes and their relationships with climate, mycorrhizal fungi, foliar nutrient concentrations, and nitrogen availability. New Phytologist 183: 980-992. https://doi.org/10.1111 /j.1469-8137.2009.02917.x

Craine, J. M., E. G. Towne, T. W. Ocheltree, and J. B. Nippert. 2012. Community traitscape of foliar nitrogen isotopes reveals $\mathrm{N}$ availability patterns in a tallgrass prairie. Plant and Soil 356: 395-403. https://doi.org/10.1007/s111 04-012-1141-7

Darimont, C. T., H. Bryan, S. M. Carlson, M. D. Hocking, M. MacDuffee, P. C. Paquet, M. H. H. Price, T. E. Reimchen, J. D. Reynolds, and C. C. Wilmers. 2010. Salmon for terrestrial protected areas. Conservation Letters 3: 379389. https://doi.org/10.1111/j.1755-263X.2010.00145.X

Darimont, C. T., T. E. Reimchen, and P. C. Paquet. 2003. Foraging behaviour by gray wolves on salmon streams in coastal British Columbia. Canadian Journal of Zoology 81: 349-353. https://doi.org/10.1139/Z02-246

Dawson, T. P., P. R. J. North, S. E. Plummer, and P. J. Curran. 2003. Forest ecosystem chlorophyll content: implications for remotely sensed estimates of net primary productivity. International Journal of Remote Sensing 24: 611-617. https://doi.org/10.1080/01431160304984

Field, R. D., and J. D. Reynolds. 2013. Ecological links between salmon, large carnivore predation, and scavenging birds. Journal of Avian Biology 44: 9-16. https://doi.org/ 10.1111/j.1600-048X.2012.05601.x

Finney, B. P., I. Gregory-Eaves, M. S. V. Douglas, and J. P. Smol. 2002. Fisheries productivity in the northeastern Pacific Ocean over the past 2,200 years. Nature 416: 729 733. https://doi.org/10.1038/416729a

Fry, B. 2006. Stable Isotope Ecology. Springer-Verlag, New York, New York, USA.

Fujiwara, M., and R. C. Highsmith. 1997. Harpacticoid copepods: potential link between inbound adult salmon and outbound juvenile salmon. Marine Ecology Progress Series 158: 205-216. https://doi.org/10.3354/meps158205

Gende, S. M., A. E. Miller, and E. Hood. 2007. The effects of salmon carcasses on soil nitrogen pools in a riparian forest of southeastern Alaska. Canadian Journal of Forest Research 37: 1194-1202. https://doi.org/10.1139/X06-318

Gende, S. M., T. P. Quinn, M. F. Willson, R. Heintz, and T. M. Scott. 2004. Magnitude and fate of salmon-derived nutrients and energy in a coastal stream ecosystem. Journal of Freshwater Ecology 19: 149-160. https://doi.org/10.1080/ 02705060.2004 .9664522

Gilbert, B. K., and R. M. Lanner. 1995. Energy, diet selection and restoration of brown bear populations. Pages 231240 in Density-dependent Population Regulation of Black, 
Brown, and Polar Bears. Proceedings of the 9th International Conference on Bear Research and Management. Edited by M. Taylor and D. L. Garshelis. International Association for Bear Research and Management, Missoula, Montana, USA.

Goodbrod, J. R., and M. L. Goff. 1990. Effects of larval population density on rates of development and interactions between two species of Chrysomya (Diptera: Calliphoridae) in laboratory culture. Journal of Medical Entomology 27: 338-343. https://doi.org/10.1093/jmedent/27.3.338

Gresh, T., J. Lichatowich, and P. Schoonmaker. 2000. An estimation of historic and current levels of salmon production in the northeast Pacific ecosystem: evidence of a nutrient deficit in the freshwater systems of the Pacific Northwest. Fisheries 25: 15-21. https://doi.org/10.1577/ 1548-8446(2000)025<0015:AEOHAC $>2.0$. CO;2

Harding, J. M. S., M. R. Segal, and J. D. Reynolds. 2015. Location is everything: evaluating the effects of terrestrial and marine resource subsidies on an estuarine bivalve. PLoS ONE 10(5): e0125167. https://doi.org/10.1371/jour nal.pone. 0125167

Heaton, V., C. Moffatt, and T. Simmons. 2014. Quantifying the temperature of maggot masses and its relationship to decomposition. Journal of Forensic Sciences 59: 676-682. https://doi.org/10.1111/1556-4029.12396

Helfield, J. M., and R. J. Naiman. 2001. Effects of salmonderived nitrogen on riparian forest growth and implications for stream productivity. Ecology 82: 2403-2409. https:// doi.org/10.2307/2679924

Helfield, J. M., and R. J. Naiman. 2006. Keystone interactions: salmon and bear in riparian forests of Alaska. Ecosystems 9: 167-180. https://doi.org/10.1007/s10021-004-00 63-5

Hilderbrand, G. V., S. D. Farley, T. A. Hanley, C. C. Schwartz, and C. T. Robbins. 2004. Importance of salmon to wildlife: implications for integrated management. Ursus 15: 1-9. https://doi.org/10.2192/1537-6176(2004)015<00 01:IOSTWI $>2.0 . \mathrm{CO} ; 2$

Hilderbrand, G. V., S. D. Farley, C. T. Robbins, T. A. Hanley, K. Titus, and C. Servheen. 1996. Use of stable isotopes to determine diets of living and extinct bears. Canadian Journal of Zoology 74: 2080-2088. https://doi. org/10.1139/z96-236

Hilderbrand, G. V., T. A. Hanley, C. T. Robbins, and C. C. Schwartz. 1999. Role of brown bears (Ursus arctos) in the flow of marine nitrogen into a terrestrial ecosystem. Oecologia 121: 546-550. https://doi.org/10.1007/s004420 050961

Hocking, M. D., and T. E. Reimchen. 2002. Salmon-derived nitrogen in terrestrial invertebrates from coniferous forests of the Pacific Northwest. BioMed Central Ecology 2: 4-14. https://doi.org/10.1186/1472-6785-2-4

Hocking, M. D., and T. E. Reimchen. 2006. Consumption and distribution of salmon (Oncorhynchus spp.) nutrients and energy by terrestrial flies. Journal of Fisheries and Aquatic Sciences 63: 2076-2086. https://doi.org/10.1139/ F06-110

Hocking, M. D., and T. E. Reimchen. 2009. Salmon species, density and watershed size predict magnitude of marine enrichment in riparian food webs. Oikos 118: 1307-1318. https://doi.org/10.1111/j.1600-0706.2009.17302.x

Hocking, M. D., and J. D. Reynolds. 2011. Impacts of salmon on riparian plant diversity. Science 331: 1609-1612. https: //doi.org/10.1126/science. 1201079
Hocking, M. D., and J. D. Reynolds. 2012. Nitrogen uptake by plants subsidized by Pacific salmon carcasses: a hierarchical experiment. Canadian Journal of Forest Research 42: 908-917. https://doi.org/10.1139/X2012-045

Hocking, M. D., R. A. Ring, and T. E. Reimchen. 2009. The ecology of terrestrial invertebrates on Pacific salmon carcasses. Ecological Research 24: 1091-1100. https://doi. org/10.1007/s11284-009-0586-5

Holtgrieve, G. W., D. E. Schindler, and P. K. Jewett. 2009. Large predators and biogeochemical hotspots: brown bear (Ursus arctos) predation on salmon alters nitrogen cycling in riparian soils. Ecological Research 24: 1125-1135. https: //doi.org/10.1007/s11284-009-0591-8

Jauquet, J., N. Pittman, J. A. Heinis, S. Thompson, N. Tatyama, and C. J. Cederholm. 2003. Observations of chum salmon consumption by wildlife and changes in water chemistry at Kennedy Creek during 1997-2000. Pages 71-88 in Nutrients in Salmonid Ecosystems: Sustaining Production and Biodiversity. Edited by J. G. Stockner. American Fisheries Society Symposium 34, Bethesda, Maryland, USA.

Johnson, S. P., and D. E. Schindler. 2009. Trophic ecology of Pacific salmon (Oncorhynchus spp.) in the ocean: a synthesis of stable isotope research. Ecological Research 24: 855-863. https://doi.org/10.1007/s11284-008-0559-0

Juen, A., and M. Traugott. 2007. Revealing species-specific trophic links in soil food webs: molecular identification of scarab predators. Molecular Ecology 16: 1545-1557. https: //doi.org/10.1111/j.1365-294X.2007.03238.x

Kauffman, J. B., R. L. Beschta, N. Otting, and D. Lytjen. 1997. An ecological perspective of riparian and stream restoration in the western United States. Fisheries 22: $12-$ 24. https://doi.org/10.1577/1548-8446(1997)022<0012:AE PORA $>2.0 . \mathrm{CO} ; 2$

Klinka, D. R., and T. E. Reimchen. 2002. Nocturnal and diurnal foraging behaviour of Brown Bears (Ursus arctos) on a salmon stream in coastal British Columbia. Canadian Journal of Zoology 80: 1317-1322. https://doi.org/10.1139/Z02123

Klinka, D., and T. E. Reimchen. 2009. Adaptive coat colour polymorphism in the Kermode Bear of coastal British Columbia. Biological Journal of the Linnean Society 98 : 479-488. https://doi.org/10.1111/j.1095-8312.2009.01306.x

Lack, D. 1966. Population Studies of Birds. Oxford University Press, London, United Kingdom.

Lackey, R. T. 2003. Nutrient addition to restore salmon runs: considerations for developing environmental protection policies and regulations. Pages 283-285 in Nutrients in Salmonid Ecosystems: Sustaining Production and Biodiversity. Edited by J. G. Stockner. American Fisheries Society Symposium 34, Bethesda, Maryland, USA.

Littke, K. M., R. B. Harrison, D. Zabowski, and D. G. Briggs. 2014. Assessing nitrogen fertilizer response of coastal Douglas-fir in the Pacific Northwest using a paired-tree experimental design. Forest Ecology and Management 330: 137-143. https://doi.org/10.1016/j.foreco.2014.07.008

Marshall, D. E., R. F. Brown, G. A. Buxton, V. D. Chahley, and D. G. Demontier. 1978. Preliminary catalogue of salmon streams and spawning escapements of Statistical Area 2E (Queen Charlotte Islands). Fisheries and Marine Service Data Report \#72. Enhancement Services Branch, Fisheries and Marine Service, Department of Fisheries and Oceans and Environment, Vancouver, British Columbia, Canada. 
Mathewson, D., M. H. Hocking, and T. E. Reimchen. 2003. Nitrogen uptake in riparian plant communities across a sharp ecological boundary of salmon density. BioMed Central Ecology 2003 3: 4. https://doi.org/10.1186/1472-67 85-3-4

McGaw, I. J. 2005. Burying behaviour of two sympatric crab species: Cancer magister and Cancer productus. Scientia Marina 69: 375-381. https://doi.org/10.3989/scimar. 2005.69n3375

Meehan, E. P., E. E. Seminet-Reneau, and T. P. Quinn. 2005. Bear predation on Pacific salmon facilitates colonization of carcasses by fly maggots. The American Midland Naturalist 153: 142-151. https://doi.org/10.1674/0003-00 31(2005)153[0142:BPOPSF]2.0.CO;2

Nadelhoffer, K. J., and B. Fry. 1994. Nitrogen isotope studies in forest ecosystems. Pages 22-44 in Stable Isotopes in Ecology and Environmental Science. Edited by K. Lajtha and R. H. Michener. Blackwell Scientific, Boston, Massachusetts, USA.

Nagasaka, A., Y. Nagasaka, K. Ito, T. Mano, M. Yamanaka, A. Katayama, Y. Sato, A. L. Grankin, A. I. Zdorikov, and G. A. Boronov. 2006. Contributions of salmon-derived nitrogen to riparian vegetation in the northwest Pacific region. Journal of Forest Research 11: 377-382. https:// doi.org/10.1007/s10310-006-0226-7

Naiman, R. J., J. M. Helfield, K. K. Bartz, D. C. Drake, and J. M. Honea. 2009. Pacific salmon, marine-derived nutrients, and the characteristics of aquatic and riparian ecosystems. American Fisheries Society Symposium 69: 395-425.

Nakajima, M., and T. Ito. 2003. Aquatic animal colonization of chum salmon carcasses in Hokkaido, northern Japan. American Fisheries Society Symposium 34: 89-97.

O'Keefe, T. C., and R. T. Edwards. 2003. Evidence for hyporheic transfer and removal of marine-derived nutrients in a sockeye stream in southwest Alaska. Pages 99-107 in Nutrients in Salmonid Ecosystems: Sustaining Production and Biodiversity. Edited by J. G. Stockner. American Fisheries Society Symposium 34, Bethesda, Maryland, USA.

Pielou, E. C. 1991. After the Ice Age: The Return of Life to Glaciated North America. University of Chicago Press, Chicago, Illinois, USA.

Quamme, D. L., and P. A. Slaney. 2003. The relationship between nutrient concentration and stream insect abundance. Pages 163-175 in Nutrients in Salmonid Ecosystems: Sustaining Production and Biodiversity. Edited by J. G. Stockner. American Fisheries Society Symposium 34, Bethesda, Maryland, USA.

Ranalli, A. J., and D. L. Macalady. 2010. The importance of the riparian zone and in-stream processes in nitrate attenuation in undisturbed and agricultural watersheds $-\mathrm{A}$ review of the scientific literature. Journal of Hydrology 389: 406415. https://doi.org/10.1016/j.jhydrol.2010.05.045

Reimchen, T. E. 1992. Mammal and bird utilization of adult salmon in stream and estuarine habitats at Bag Estuary, Moresby Island. Canadian Wildlife Service, Queen Charlotte City, British Columbia, Canada.

Reimchen, T. E. 1994. Further studies of black bear and chum salmon in stream and estuary habitats at Bag Harbour, Gwaii Haanas. Canadian Parks Service, Queen Charlotte City, British Columbia, Canada.

Reimchen, T. E. 1998. Nocturnal foraging behaviour of Black Bears, Ursus americanus, on Moresby Island, British Columbia. Canadian Field-Naturalist 112: 446-450. Accessed
10 April 2018. https://www.biodiversitylibrary.org/item/ 106776\#page/462/mode/1up.

Reimchen, T. E. 2000. Some ecological and evolutionary aspects of bear-salmon interactions in coastal British Columbia. Canadian Journal of Zoology 78: 448-457. https:// doi.org/10.1139/z99-232

Reimchen, T. E., and C. H. Fox. 2013. Fine-scale spatiotemporal influences of salmon on growth and nitrogen signatures of Sitka spruce tree rings. BioMed Central Ecology 2013 13: 38. https://doi.org/10.1186/1472-6785-13-38

Reimchen, T. E., D. Mathewson, M. D. Hocking, J. Moran, and D. Harris. 2003. Isotopic evidence for enrichment of salmon-derived nutrients in vegetation, soil and insects in riparian zones in coastal British Columbia. Pages 59-69 in Nutrients in Salmonid Ecosystems: Sustaining Production and Biodiversity. Edited by J. G. Stockner. American Fisheries Society Symposium 34, Bethesda, Maryland, USA.

Rieman, B. E., C. L. Smith, R. J. Naiman, G. T. Ruggerone, C. C. Wood, N. Huntly, E. N. Merrill, J. R. Alldredge, P. A. Bisson, J. Congleton, K. D. Fausch, C. Levings, W. Pearcy, D. Scarnecchia, and P. Smouse. 2015. A comprehensive approach for habitat restoration in the Columbia Basin. Fisheries 40: 124-135. https://doi.org/10.1080/0363 2415.2015.1007205

Shean, B. S., L. Messinger, and M. Papworth. 1993. Observations of differential decomposition on sun exposed $\mathrm{v}$. shaded pig carrion in coastal Washington State. Journal of Forensic Sciences 38: 938-949. https://doi.org/10.1520/ JFS13492J

Slaney, P. A., and A. D. Marten. 1997. The watershed restoration program of British Columbia: accelerating natural recovery processes. Water Quality Research Journal of Canada 32: 325-346.

Slaney, P. A., B. R. Ward, and J. C. Wightman. 2003. Experimental nutrient addition to the Keogh River and application for the Salmon River in coastal British Columbia. Pages 111-126 in Nutrients in Salmonid Ecosystems: Sustaining Production and Biodiversity. Edited by J. G. Stockner. American Fisheries Society Symposium 34, Bethesda, Maryland, USA.

Stalmaster, M. V., and J. A. Gessaman. 1982. Food consumption and energy requirements of captive Bald Eagles. Journal of Wildlife Management 46: 646-654. https://doi. org/10.2307/3808555

Stockner, J. G., and J. I. Ashley. 2003. Salmon nutrients: closing the circle. Pages 3-15 in Nutrients in Salmonid Ecosystems: Sustaining Production and Biodiversity. Edited by J. G. Stockner. American Fisheries Society Symposium 34, Bethesda, Maryland, USA.

Thomas, S. C., C. B. Halpern, D. A. Falk, D. A. Liguori, and K. A. Austin. 1999. Plant diversity in managed forests: understory responses to thinning and fertilization. Ecological Applications 9: 864-879. https://doi.org/10.1890/10510761(1999)009[0864:PDIMFU]2.0.CO;2

Thorne, R. E., G. L. Thomas, and M. A. Bishop. 2006. Alternative seafood waste disposal procedures for Alaskan waters. Oceans 14: 49-52. https://doi.org/10.1109/OCE ANS.2006.306979

Waring, R. H., and J. F. Franklin. 1979. Evergreen coniferous forests of the Pacific Northwest. Science 204: 13801386. https://doi.org/10.1126/science.204.4400.1380

Wilkinson, C. E., M. H. Hocking, and T. E. Reimchen. 2005. Uptake of salmon-derived nitrogen by mosses and liverworts in Coastal British Columbia. Oikos 108: 85-98. https://doi.org/10.1111/j.0030-1299.2005.13277.x 
Willson, M. F., and K. C. Halupka. 1995. Anadromous fish as keystone species in vertebrate communities. Conservation Biology 9: 489-497. https://doi.org/10.1046/j.15231739.1995.09030489.X

Wipfli, M. S., J. P. Hudson, J. P. Caouette, and D. T. Chaloner. 2003. Marine subsidies in freshwater ecosystems: salmon carcasses increase the growth rates of streamresident salmonids. Transactions of the American Fisheries Society 132: 371-381. https://doi.org/10.1577/1548-8659 (2003)132<0371:MSIFES $>2.0 . \mathrm{CO} ; 2$
Yoder, B. J., and R. E. Pettigrew-Crosby. 1995. Predicting nitrogen and chlorophyll content and concentrations from reflectance spectra (400-2500 nm) at leaf and canopy scales. Remote Sensing of Environment 53: 199-211. https: //doi.org/10.1016/0034-4257(95)00135-N

Received 28 June 2017

Accepted 29 January 2018 